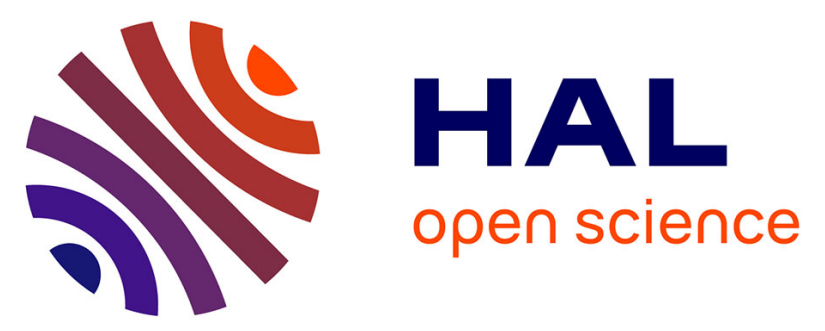

\title{
High pressure and temperatures during the early stages of tungsten deposition at Panasqueira revealed by fluid inclusions in topaz
}

Michel Cathelineau, Marie-Christine Boiron, Christian Marignac, Maxime Dour, Mélanie Dejean, Eleonora Carocci, Laurent Truche, Filipe Pinto

\section{To cite this version:}

Michel Cathelineau, Marie-Christine Boiron, Christian Marignac, Maxime Dour, Mélanie Dejean, et al.. High pressure and temperatures during the early stages of tungsten deposition at Panasqueira revealed by fluid inclusions in topaz. Ore Geology Reviews, 2020, 126, pp.103741. 10.1016/j.oregeorev.2020.103741 . hal-02930011

\section{HAL Id: hal-02930011 \\ https://hal.univ-lorraine.fr/hal-02930011}

Submitted on 4 Sep 2020

HAL is a multi-disciplinary open access archive for the deposit and dissemination of scientific research documents, whether they are published or not. The documents may come from teaching and research institutions in France or abroad, or from public or private research centers.
L'archive ouverte pluridisciplinaire HAL, est destinée au dépôt et à la diffusion de documents scientifiques de niveau recherche, publiés ou non, émanant des établissements d'enseignement et de recherche français ou étrangers, des laboratoires publics ou privés. 
High pressure and temperatures during the early stages of tungsten deposition at Panasqueira revealed by fluid inclusions in topaz

(1)

Michel Cathelineau1, Marie-Christine Boiron1, Christian Marignac1, Maxime Dour1, Mélanie Dejean1, Eleonora Carocci1, Laurent Truche2 and Filipe Pinto3

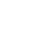

1 Université de Lorraine, CNRS, GeoRessources, 54000, Nancy, France

michel.cathelineau@univ-lorraine.fr, marie-christine.boiron@univ-lorraine.fr,

christian.marignac@univ-lorraine.fr, maxime.dour1@uqac.ca, melandejean@gmail.com, eleonora.carocci@univ-lorraine.fr

2Université de Grenoble-Alpes, ISTerre, F-38041 Grenoble, France

laurent.truche@univ-grenoble-alpes.fr

3Beralt Tin \& Wolfram Portugal, 6225-051 Barroca Grande, Portugal \& Instituto de Ciências da Terra, Rua Campo Alegre 687, 4169-007 Porto, Portugal

Filipe.Pinto@beraltportugal.pt 


\section{Abstract}

The Variscan vein-type Panasqueira W-Sn(Cu) deposit, one of the main tungsten deposits in Western Europe, has a long and complicated geological history. The first vein infillings, which consist of the quartz-wolframite association as well as the first generation of topaz, underwent significant deformation. As a consequence, most fluid inclusions of the earliest hydrothermal event are deformed and destroyed. Two preserved fluid inclusion assemblages are, however, found in the topaz overgrowth band and are dense aqueous-carbonic inclusions as well as dense $\mathrm{CO}_{2}$ dominated fluid inclusions. The P-T conditions of fluid trapping are constrained by using the intersection between isochores, as well as graphite-water equilibrium data and yield the following trapping conditions: $500 \pm 20^{\circ} \mathrm{C}$ and $250 \pm 20 \mathrm{MPa}$. These P-T conditions are incompatible with fluid unmixing. Fluid chemistry results from water-graphite equilibrium, probably in metapelites, at two distinct temperatures: around $450-500^{\circ} \mathrm{C}$ for the predominant aqueous-carbonic fluid, and higher temperatures of maximal $550^{\circ} \mathrm{C}$ for the $\mathrm{CO}_{2}$-rich fluid enriched in $\mathrm{N}_{2}$. These P-T estimates are consistent with deep crustal levels around 8-10 km depth and a high geothermal gradient around c. $60^{\circ} \mathrm{C} / \mathrm{km}-1$. The ascending non-magmatic fluids, enriched in volatiles, are essential in the ore genesis.

The high thermal gradients may be related either to new magma pulse after the formation of the Panasqueira granite intrusion or to anomalous heat flux produced by the hot fluids ascending from migmatitic levels present at greater depth. This hypothesis necessitates to consider the role of a crustal weakness, which is attested both by the successive intrusions of several granitic magmas at the same place, and the presence of inherited quartz filled structures so-called Seixo-Bravo found only in the Panasqueira area.

Keywords: Metamorphic fluids; Topaz; Tungsten; P-T path; Deep crustal level; Panasqueira.

\section{Introduction}

The Variscan Panasqueira W-Cu-Sn deposit, one of the prominent W deposits in Western Europe, has for a long time been considered a granite-related stockwork of quartz-wolframite veins, related to a concealed intrusion, at a rather shallow crustal level (Kelly and Rye, 1979). The paragenetic succession established in this early pioneering study was later corrected and completed by Polya et al. (2000), Lourenço (2002), and Pinto et al. (2015). It was the basis of the paragenetic scheme used by all further studies. 
On this basis, several fluid inclusions (FI) studies intended to estimate ore depositing conditions (Kelly and Rye 1979, Bussink 1984, Noronha et al. 1992, Polya et al. 2000, Lourenço 2002, Lecumberri-Sanchez et al. 2017, Jaques and Pascal 2017). Earliest studies by Kelly and Rye (1979) focused primarily on quartz and, to a lesser degree, on apatite and siderite. They used a debatable postulate that fluids were trapped under conditions close to boiling, and homogenisation temperatures have therefore been considered as trapping temperatures. Kelly and Rye (1979) concluded, therefore, that most mineral assemblages in the deposit formed at around $230-360^{\circ} \mathrm{C}$ at low pressures (below $15 \mathrm{MPa}$ ), the concealed granite intrusion controlling a unique hydrothermal megacycle. They concluded that the burial was rather shallow, between $600 \mathrm{~m}$ and $1300 \mathrm{~m}$ at a maximum. Bussink (1984) adopted the same line of interpretation, e.g., the fact that the presence of both vapour-dominated inclusions and aqueous carbonic liquids, is indicative of volatile unmixing. He considered the ore deposition depth to be between 1600 and $2000 \mathrm{~m}$ with pressure around $15 \mathrm{MPa}$, with veins connected to the surface. However, this hypothesis could not explain the presence of some dense fluid inclusions, leading Bussink et al. (1984) to suggest a significant overpressure (150 MPa) at the very first stage of vein opening. Then, Polya (1989) analysed FI leachates after crushing and indicate that ore-forming fluids were low salinity aqueous fluids of meteoric origin, in equilibrium with $\mathrm{K}$-feldspar, albite and muscovite at $350-400^{\circ} \mathrm{C}$. The inferred pressure, less than 500 bars, was deduced from the available literature. Later, Noronha et al. (1992) proposed that fluid pressure was fluctuating below lithostatic pressure. They did not provide, however, precise ranges of temperatures and pressures, except that temperatures could be higher than $350^{\circ} \mathrm{C}$. Foxford et al. (2000) considered the vein swarm as formed through extensional failure driven by hydraulic-valving at moderate differential stresses in a compressive crustal regime. Based on statistical data on the geometric characteristics of the veins and deformation models, they deduce that the veins developed in the supralithostatic pore pressure region beneath a low permeability cover. Still, they did not venture to provide a pressure estimate in a pressure-depth diagram.

Lourenço (2002) confirmed that mineralisation was associated with $\mathrm{CO}_{2}-\mathrm{CH}_{4}-\mathrm{N}_{2}$ aqueouscarbonic fluids with low salinity $(5-10 \mathrm{wt} \% \mathrm{NaCl}$ equiv.) and minimum entrapment temperature close or below $300^{\circ} \mathrm{C}$. As Noronha et al. (1992), Lourenço (2002) concluded that most fluids are of metamorphic derivation. Campbell et al. (1988) and Lüders (1996) studied using infra-red microscopy wolframite-hosted fluid inclusions. In wolframite from an unknown stage, Lüders (1996) described most FI as aqueous fluids with salinities ranging from 7 to 20 $w t \% \mathrm{NaCl}$ equiv., as $\mathrm{CO}_{2}$ could not be detected by microthermometry. On the contrary, Campbell et al. (1988) considered the predominant Fls in wolframite to be rich in volatiles, but microthermometric measurements could not confirm $\mathrm{CO}_{2}$. However, they found two threephase Fls containing liquid $\mathrm{CO}_{2}$ but did not provide data on this type of FI. Using LA-ICP-MS 
analyses of unspecified volatile-bearing FI from the quartz veins, Lecumberri-Sanchez et al. (2017) concluded that fluids were magmatic and transported W, the wolframite precipitation being entirely dependent on iron availability in the altered wall rocks.

Isochores in detailed P-T diagrams lack in most studies, except that of Jaques and Pascal (2017). The latter proposed a rather high-pressure estimate (c. $300 \mathrm{MPa}$ ) using a temperature issued from arsenopyrite geothermometry. Other independent temperature estimates were recently acquired by Codeço et al. (2017), using the Ti-in-quartz geothermometer, and Codeço et al. (2019) using B isotopes. The Ti-in-quartz geothermometer, applied to wall rock hydrothermal quartz from the earliest stage of tourmalinisation preceding the $\mathrm{W}$ deposit, yields estimates of $420-550{ }^{\circ} \mathrm{C}$, for an inferred pressure of $100 \mathrm{MPa}$ derived from Foxford et al. (2000), and $404-530^{\circ} \mathrm{C}$, for a lower value of $20 \mathrm{MPa}$, closer to that of Kelly and Rye (1979). The B thermometer proposed by Codeço et al. (2019) assumes isotopic equilibrium between tourmaline and muscovite, and yielded a range of temperatures, from a $400-460^{\circ} \mathrm{C}$ average interval for the formation of the vein selvages down to c. $250^{\circ} \mathrm{C}$ for the latest stages. These estimates are in sharp contrast with most of the previously published data. Finally, other studies such as Launay et al. (2018) focused on fluid flow vectors deduced from tourmaline growth features at the vein margins and showed that fluids flowed radially around the greisenised cupola; hence they equally concluded for a magmatic origin for the fluid.

In brief, although extensively studied, the P-T-X evolution of ore fluids at Panasqueira during its long history remains controversial, as most published estimations disagree with each other. Furthermore, preliminary FI studies of the first generation of quartz (Qtzl) have shown that decrepitation and deformation destroyed most early fluid inclusions trapped in quartz (Cathelineau et al., 2017). This critical fact, unfortunately, was overlooked in all previous studies. The lack of consensus on the $P$ and $T$ evolution at Panasqueira prompted us to perform a detailed review of fluid inclusion assemblages. Recent mine galleries at Panasqueira have provided new and excellent samples, in particular for the early-stage mineral assemblages, such as topaz veins. These veins crosscut the oxide (wolframite-quartz) stage assemblages, and show exceptionally well-preserved fluid inclusions. We studied thus early mineral stages (wolframite-quartz, and then topaz-pyrrhotite) in detail by using all available tools necessary for the determination of detailed bulk chemistry and fluid density to propose an accurate P-T reconstruction and discuss the depth and factors controlling the ore genesis.

\section{Geology and sampling}

The Panasqueira W-Sn-Cu deposit is located in the Portuguese part of the Variscan Central Iberian Zone (CIZ) (Fig. 1A and B). The mine, active for more than 100 years, was for a long 
time one of the largest tungsten producers in Western Europe. The sum of the past production of at least 88 kt W in 1947-2014 (Vigne et al., 2018) and of remaining reserves + resources of $\sim 23 \mathrm{kt} \mathrm{W}$ (Almonty Industries et al., 2016), yield to at least c. $111 \mathrm{kt} \mathrm{W}$, thus contributing for more than one third to the ClZ tungsten endowment.

The deposit occurs in greenschist facies micaschists belonging to the Beira Schists Complex (Diez-Fernandez et al., 2013), which forms part of the main autochthonous terrane in the Central Iberian Zone. This terrane comprises a thick sequence of late Ediacarian-Cambrian metasedimentary rocks, the Schist-Greywacke Complex, also called Beira Group, overlain unconformably by the Early Ordovician Armorican Quartzite as shown in the cross-section in Figure 1C (Diez-Fernandez et al., 2013). The metasedimentary package is divided into three units (Diez-Fernandez et al., 2013): (1) a lower unit ( $\geq 2000 \mathrm{~m}$ thick), monotonous alternation of slates and sandstones (Ediacarian), with at the top intercalation of thick (up to $400 \mathrm{~m}$ ) carbonate levels and several black slate layers (encompassing the upper Ediacarian and lower Cambrian); (2) a middle unit ( 500 m thick), characterised by abundant sandstones and conglomerates; and (3) an upper unit ( 1000 m thick), mostly composed of greenish-grey slates, with sandstone and conglomerate layers.

The tectonic and thermal Variscan history of the CIZ, which begins in the Early Carboniferous and ends in the Early Permian, is subdivided into five deformation events, D1 (350 $\pm 4 \mathrm{Ma}$ ) to D5 (290 Ma) (Diez-Fernandez et al., 2016, Diez-Fernandez and Pereira, 2017, Rubio-Pascual et al., 2013). The D2 -D5 evolution is characterised by large-scale crustal melting, resulting from a combination of mid-crustal post-thickening heating and mantle-derived heat input at the base of the continental crust (Pereira et al., 2017). The D3 to D5 evolution corresponds to a long series of episodic intra-crustal transcurrent deformation, initiated at ca. 315-310 Ma by the development of $1 \mathrm{~km}$ - to $10 \mathrm{~km}$-sized NW-SE to N-S upright F3 folds, with an S3 axialplane schistosity, and followed by D4 (c. 309-305 Ma) left-lateral and D5 (c. 304-295 Ma) dextral faulting (Diez-Fernandez et al., 2017; and references therein). Crustal melting and concomitant mantle-derived heat input were continued throughout D3 to D5, with the pervasive emplacement of syn- to post-kinematic granite plutons, in three pulses roughly coincident with the D3 to D5 events: syn-kinematic porphyritic biotite monzogranites and leucogranites (c. 315-310 Ma); late-kinematic D3 (c. 309-301 Ma) and post-kinematic (c. 295-287 Ma) biotite \pm cordierite monzogranites and granodiorites, with ferroan-potassic sub-alkaline granites at $\mathrm{c}$. 295-290 Ma (e.g., Dias et al., 1998; Mateus and Noronha, 2010; Sant'Ovaia et al., 2010; Fernandez-Suarez et al., 2011). Water-absent dehydration melting (biotite incongruent melting) produced cordierite-bearing diatexites in the cores of D2 migmatitic domes (PereiraGomez and Rodriguez-Alonso, 2000).

The Panasqueira deposit consists of a swarm of sub-horizontal mineralised quartz veins also containing $\mathrm{Sn}$ and $\mathrm{Cu}$ and extending for over $10 \mathrm{~km} 2$ with a vertical extent of around $300 \mathrm{~m}$ 
(Fig. 2). The formation and opening of the veins have been variously interpreted in terms of either extension during granite emplacement (Foxford et al., 2000) or to transpression with joint development during the late orogenic stages (Jacques et al., 2017). Sets of barren quartz veins, the so-called "Seixo Bravo" veins, are crosscut by the sub-horizontal W-quartz veins. They are decimetric to metric in thickness and extension between 100 to $200 \mathrm{~m}$. They are densely distributed in the mine area but are quasi-absent outside the deposit. They are subvertical, forming conjugate sets at c. N110-120 and $150-170^{\circ} \mathrm{E}$ of quartz filled veins. They are highly deformed, the veins having suffered buckling and mullioning during $S 3$, and are therefore clearly late kinematic for D3. A large, concealed granite body with a laccolith shape (Ribeiro, 2017) is associated with a contact metamorphic aureole outcropping as spotted schists. At the top of this body, layered magmatic and a cupola of rare metal granites (Kelly and Rye, 1979, Bussink, 1984, Marignac et al., 2020) are more or less affected by greisenisation and crosscut by the mineralised vein system.

Samples studied come from two main zones (Fig. 2): i) the topaz zone located in the southwestern part of the deposit (mining works at level 1, in particular, the adit L1-D29-513-AW14, eastern side), and ii) wolframite-quartz veins from the "bank area" located at the first level, now inaccessible, but for which an extensive sampling from years ' 70 s was available by the authors, and from level 3 .

\section{Methods}

\subsection{Paragenetic associations}

Following petrographic examination with an OLYMPUS BX51 (transmitted and reflected light) optical microscope and a VHX-200 KEYENCE digital microscope, selected samples were studied with a Schottky-FEG (Field Emission Gun) JEOL J7600F scanning electron microscope (SEM) equipped with an SDD-type EDS spectrometer at the GeoRessources Laboratory (Nancy, France). Backscattered electron (BSE) images were obtained by setting the acceleration voltage at $15 \mathrm{kV}$.

Micro-XRF mapping was carried out using the Bruker-Nano M4 Tornado instrument. This system has an Rh X-ray tube with a Be side window and polycapillary optics giving an X-ray beam with a diameter of 25-30 $\mu \mathrm{m}$ on the sample. The X-ray tube was operated at $50 \mathrm{kV}$ and $200 \mu \mathrm{A}$. X-rays are detected by a $30 \mathrm{~mm} 2 \mathrm{xflash} \AA \mathrm{SDD}$ with an energy resolution of $<135 \mathrm{eV}$ at $250,000 \mathrm{cps}$. All analyses were carried out at $2 \mathrm{kPa}$ vacuum. Main elements such as $\mathrm{U}, \mathrm{Ca}$, $\mathrm{Mg}, \mathrm{Mn}, \mathrm{Fe}, \mathrm{Ti}, \mathrm{Al}, \mathrm{K}, \mathrm{Na}$, and $\mathrm{Si}$ were mapped, and composite images were generated.

\subsection{Fluid inclusions}

Fluid evolution has been studied by looking at relationships between fluid inclusions, their host mineral, the geometry of the host microstructures, and the location of ore minerals. Fluid 
inclusions assemblages were related to the relative chronology of mineral assemblages. Notation of the fluid inclusion types follows nomenclature previously published (Boiron et al., 1992), which takes into account the nature of the dominant chemical phases and phase changes observed. It is based on the total homogenisation Th ( $\mathrm{L}-\mathrm{V}$ to the vapour noted V, L$\mathrm{V}$ to the liquid noted $\mathrm{L}$ ) and the quantity of $\mathrm{C}-\mathrm{H}-\mathrm{O}-(\mathrm{N}-\mathrm{S})$ species: subscript $\mathrm{C}$, when $\mathrm{C}-\mathrm{H}-\mathrm{O}-$ $S$ species are the only components and water is not visible; $c-w$, when water and homogenisation of carbonic phase are observable; w-c, when both water and volatiles $\left(\mathrm{CO}_{2}\right.$, $\mathrm{CH}_{4}$, and $\mathrm{N}_{2}$ species) are present, but gases are detected only by clathrate melting and Raman spectroscopy.

Microthermometry was carried out on fluid inclusions using a Linkam® MDS600 heatingcooling stage, adapted to an Olympus $\AA$ microscope at the GeoRessources laboratory in Nancy (France). The following microthermometric parameters have been measured: the melting temperatures of ice ( $\mathrm{Tm}$ ice), $\mathrm{CO}_{2}$ melting and clathrate dissociation ( $\mathrm{Tm} \mathrm{CO} 2$ and $\mathrm{Tm} \mathrm{cl}$ ), $\mathrm{CO}_{2}$ homogenisation ( $\mathrm{Th} \mathrm{CO}_{2}$ ), and total homogenisation temperature (Th). The temperatures of phase changes have a precision of about $\pm 0.1^{\circ} \mathrm{C}$ for $\mathrm{Tm}$ ice, $\mathrm{Tm} \mathrm{CO}_{2}, \mathrm{Th} \mathrm{CO}_{2}$, and $\mathrm{Tm} \mathrm{cl}$, and $\pm 1^{\circ} \mathrm{C}$ for $\mathrm{Th}$, whereas the accuracy, is better than $0.5^{\circ} \mathrm{C}$ in the low-temperature range and better than $5^{\circ} \mathrm{C}$ at high temperatures. The volumetric fraction of the volatile phase (fvp) was estimated by reference to the volumetric chart of Roedder (1979).

The analysis of gas species of the volatile phase was performed with a Dilor-Labram Raman microspectrometer at GeoRessources in Nancy (France) on aqueous-carbonic inclusions previously studied by microthermometry (Dubessy et al., 1989). The density of the volatile phase (dv) and the bulk composition were calculated using programs (Q2 and ICE) developed by Bakker (1997) using equations of state from Thiery et al. (1994) and Duan et al. (1996). Isochores of fluid inclusions have been calculated using the ISOC program (Bakker, 2003) based on the equations of state from Bowers and Helgeson (1983) reviewed by Bakker (1999).

\section{Results}

\subsection{Mineral associations: wolframite-quartz and topaz-sulphide}

The detailed paragenetic succession of the first mineral infillings, which is the prerequisite to any reliable geochemical or fluid inclusion study, is presented in Fig. 3. The following observations concern, thus, the three early paragenetic stages corresponding to the early tourmaline (+rutile) stage, which precedes the oxide stage (quartz-wolframite), responsible for more than $90 \%$ of the exploited wolframite, and the sulphide stage (pyrrhotite, sphalerite, chalcopyrite). These stages broadly correspond to those already defined by Kelly and Rye (1979) and used in all further studies. The differences concern a series of minerals which are found spatially associated with these three first assemblages but considered as formed later 
on by dissolution and replacement (muscovite, apatite, siderite). Thus, geodes formed during a later stage so-called IV, are found sporadically in the deposit and consist in nice euhedral infillings of quartz IV, and other minerals noted IV by reference to stage IV: wolframite IV, (rare topaz IV), abundant arsenopyrite, muscovite, cassiterite IV, apatite and siderite. Besides, in addition of cassiterite IV, other later cassiterites were also found during later stages (Pinto et al.,2015).

In the present work, we only considered non-debatable textural features for establishing the relative vein chronology for the main and earliest stages, and do not discuss the accessory minerals found in fissures, reopened selvages, vugs, and dissolution zones. Only two criteria were used: (i) the intersection of veins (or veinlets or microcracks), each bearing a distinct mineral assemblage (notably, a monomineralic one, fortunately frequently encountered), and (ii) the infilling sequence in a demonstrably open space. Ideally, these two criteria are simultaneously used, for instance, in the crack-seal veins. These criteria have been applied to each scale of observation, from the "outcrop" level (mining works) to the microscopic level. At the sample scale, the required scale of observation may be often wider than the thin section dimensions, a difficulty related to the endowment of the deposit, but which can be alleviated by using sample-scale scanning systems (micro-XRF).

At the "pillar" scale, a "pulsed" story is evident, marked by the succession of a series of opening/closing events, each one with its own mineralogical and structural imprint, defining a series of three early stages (I to III) (Fig. 3). Each of the first three stages (I-III) represents a full cycle of opening-complete infilling by a specific set of minerals:

- Stage I: after pervasive tourmalinisation of the wall rocks (Stage 0), wolframite (Wfm) crystallised as euhedral prisms at the fracture edges (Carocci et al., 2018, 2019, 2020). It was followed by massive quartz (Qtz I) precipitation following alpine fissure type opening, with development of euhedral Wfm and then a nearly full vein infilling by Qtz I (Fig. 4a to d).

- Stage II: a renewal of opening and vein filling by quartz and wolframite succeeded to stage I. Comb quartz precipitation occurred in a marked crack-seal mechanism. Meanwhile, deformation with a multi-crack opening sub-parallel to the vein plane happened in the stage I veins. As a result, wolframite crystals were fragmented (Fig. $4 \mathrm{e}$ and $4 \mathrm{f}$ ), and each crack was healed/sealed by thin, newly formed quartz Qtz II. Together, these two stages were responsible for more than $90 \%$ of the vein infilling at Panasqueira, and contain most of the $\mathrm{W}$ deposited. Thus, photographs and the scheme Fig. 4 (b, c, d, and e) are representative of hundreds of veins identified in the deposit. Wolframite is, however, heterogeneously distributed, and is often absent on the edge of veins.

- Stage III: sulphides filled large volumes developed around fracture zones affecting the previous veins from Stage I-II. The openings are generally oblique to the oldest Wfm-Qtz I or Qtz II elongation. 
Three substages are distinguished: III-a, characterised by topaz deposition, with subordinated cassiterite; III-b, marked by the sulphide deposition (sphalerite, pyrrhotite, chalcopyrite, in this order, pyrrhotite being by far the most abundant); and III-c, corresponding to the replacement of pyrrhotite by pyrite (Fig. 3). Owing to the utmost importance of topaz for deciphering the PT-X fluid evolution (see below), some details are now provided on sub-stage III-a.

Topaz is commonly found as veins, subparallel to the earlier quartz veins. Compared to stage I-II quartz veins, the topaz veins either developed independently or intersected them. Topaz veins are either independent veins out of the stage I-II quartz veins or crosscut them. Separate topaz veins typically present the following sequence: first comb topaz; sulphides, first sphalerite, then pyrrhotite (Fig. 5 a and b). Thus, the topaz deposition immediately preceded sulphide deposition. The recent expansion of mine works towards the SW revealed a specific abundance of these topaz-sulphide veins; this area is therefore called the "Topaz zone" in which cassiterite is widespread (Fig. 2). This local abundance is also pointed out by Mateus et al., (2020) who confirm that these veins are devoided of muscovite selvage, and extend from the SW to the NW sector of the mine. Similar topaz veins or veinlets crosscut the QtzI-W-ore veins (Fig. $5 \mathrm{c}$ and d) and precede later massive sulphides from stage III-b (Fig. 5b). Topaz also replaces quartz as disseminated crystals, associated with cassiterite, and locally related to ductile shearing of Qtz I or Qtz II (Fig. 6). Finally, topaz crystallised in between host rock and wolframite, at the vein selvage, thanks to the reopening of this boundary. This latter observation explains why topaz was considered part of stage I by Kelly and Rye (1979) and subsequent workers. It is nevertheless repeatedly observed that topaz overprinted wolframite. The wolframite clasts are thus included in topaz, as demonstrated by the micro XRF mapping (Fig. 7).

Thus, topaz formed during a single episode, after stage I wolframite, and precedes sulphide deposition (sphalerite, pyrrhotite, chalcopyrite), which characterises stage III. All other minerals found in the topaz veins belong to later stages, and replace locally and partially euhedral topaz crystals: muscovite, arsenopyrite, and chlorite (Carocci, 2019).

At the exception of isolated topaz-pyrrhotite veins, stages II and III most often correspond to the opening of fractures within earlier vein systems from stage I. The reopening may occur anywhere, either at the boundaries or in the central part, of the previous vein. The successive openings are not necessarily parallel, and indeed they rarely are. Intense dissolution/replacement processes accompany the opening during Stage III.

\subsection{Fluid inclusions results}

\section{Fluid characterisation}

Table 1 summarises the microthermometric data obtained on fluid inclusions studied in quartz $\mathrm{I}$ and topaz from the whole mineral sequence. No reliable inclusions could be identified, 
unfortunately, in Quartz II. Table 2 shows the representative calculated bulk compositions and corresponding microthermometric and Raman data of the selected fluid inclusion types. The predominant type consists of aqueous-carbonic fluid inclusions that can be further subdivided into three sub-types:

- Lc-w inclusions are aqueous-carbonic fluid inclusions whose volatile phase homogenises to the vapour phase $\left(\mathrm{Th}_{\mathrm{CO}}\right.$ ) and whose total homogenisation (Th) occurs into the liquid aqueous phase; their volumetric fraction of the volatile phase (fvp) ranges from 20 to $30 \%$.

- Lw-c inclusions are aqueous-carbonic fluid inclusions with an fvp of around 30\%, and the Th $\mathrm{CO}_{2}$ is not observable. Some of them show a $\mathrm{Tm} \mathrm{CO}_{2}$, a clathrate melting temperature ( $\mathrm{Tm}$ $\mathrm{Cl}$ ), and total homogenisation (Th) to the liquid phase.

- Lc-(w) inclusions are high-density carbonic-aqueous inclusions dominated by volatiles, with an fvp higher than $90 \%$. The nucleation of clathrates also reveals water. They homogenise into the liquid carbonic phase.

Quartz I: Aqueous-carbonic fluid inclusions are the predominant inclusions. Quartz I domains are full of inclusions and are surrounded by a later clear quartz corresponding to recrystallised areas during an unknown stage, probably later than the three first stages (Fig. 8 a, b, and e). In quartz I (and II), most fluid inclusions are affected by deformation (Fig. 8a and b). The largest Fls are highly irregular, with dendritic textures indicating stretching and re-equilibration (Vityk and Bodnar, 1995, Diamond, 2003) processes under ductile conditions (Fig. $8 \mathrm{c}$ and d). Most of them are empty. The boundary between inherited Qtz I and clear quartz is generally difficult to establish (Fig. 8 a, e and f). In Qtz I, close to clear quartz, a few smaller deformed Lw-c fluid inclusions are dispersed. The remaining $\mathrm{FI}$ content shows significant variability in the volatile/water ratio and $\mathrm{CO}_{2} / \mathrm{CH}_{4}$ ratio (Fig. 8f). The melting temperature of $\mathrm{CO}_{2}(\mathrm{Tm} \mathrm{CO} 2)$ ranges from -60.8 to $-58.1^{\circ} \mathrm{C}$ (Table 1 ). $\mathrm{Tm} \mathrm{cl}$ ranges from 5.3 to $10.1^{\circ} \mathrm{C}$ and $\mathrm{Tm}$ ice from 7.8 to $-4.6^{\circ} \mathrm{C}$. Total homogenisation temperatures range from 198 to $232^{\circ} \mathrm{C}$. In clear quartz, fluid inclusions are frequently absent (Fig. 8e). Inclusions from quartz Qtz II, could not be studied due to their too small size or contorted shape.

Topaz I and II: Comb topaz in veins is consistently polyphase. A first-generation (Toz I) is clouded by decrepitated or deformed inclusions (Fig. 9a to c), having lost their fluid content and may present evidence of plastic deformation. The overgrowing rims (Toz II) are never deformed, close to sulphides (Fig. $9 \mathrm{a}$ and b), and contain a lesser quantity (clearer crystals) of preserved fluid inclusions (Fig. 9d). The Toz I to II transition was, therefore, simultaneous with the deposit scale decrepitation event that also affected the early fluid inclusions present in Qtz I and II.

The three main types of FI (Lc-w, Lw-c, and Lc-(w)) form distinct FI assemblages in topaz II (Fig. 10a). Clusters of Lc-w FI dispersed in clear topaz constitute the first FI assemblage (FIA) 
and may be considered as primary FI. Small fluid inclusions planes (FIP) contain Lc-(w) FIA. The latter can be regarded as pseudo-secondary inclusions following the terminology of Roedder (1979) and Bodnar (2003). These FIPs do not crosscut Toz I, for instance, and their extension is limited to parts of Toz II (Fig. 10a to 10d).

The first FIA Lc-w inclusions (Fig. 10b) are of 15 to $30 \mu \mathrm{m}$ in size and showed fvp ranging from 20 to 30 vol.\%. $\mathrm{Tm} \mathrm{CO}_{2}$ ranges from -61.7 to $-57.4{ }^{\circ} \mathrm{C}, \mathrm{Th} \mathrm{CO}_{2}(\mathrm{~L}+\mathrm{V} \rightarrow \mathrm{V})$ ranges from 10.6 to $19.4{ }^{\circ} \mathrm{C}$ (Table 1). Tm cl ranges from 6.1 to $9.8^{\circ} \mathrm{C}$ and $\mathrm{Tm}$ ice from -6.9 to $-4.4{ }^{\circ} \mathrm{C}$. Total homogenisation temperatures for LC-w inclusions range from 250 to $295^{\circ} \mathrm{C}$.

The second FIA characterised by Lw-c inclusions (Fig. $10 \mathrm{c}$ ) does not show visible Th $\mathrm{CO}_{2}$. $\mathrm{Tm} \mathrm{CO} 2$ is observed only in a few inclusions between -61.7 and $-58.4^{\circ} \mathrm{C} \mathrm{Tm} \mathrm{cl} \mathrm{ranges} \mathrm{from} 5.1$ to $8.4^{\circ} \mathrm{C}$; $\mathrm{Tm}$ ice from -6.9 to $-4.3^{\circ} \mathrm{C}$ and Th from 245 to $255^{\circ} \mathrm{C}$.

The third FIA is represented by carbonic (-aqueous) fluid inclusions (Lc-(w)) (Fig. 10d). These $\mathrm{FI}$ are 15 to $40 \mu \mathrm{m}$ in size and often display a crystal negative shape (Fig. 10d). They are onephase or two-phase FI (Fig. 10d) at room temperature. Thus, water can occur either as a thin meniscus up to 10 vol.\% of the fluid inclusion volume (LC-(w)) or is not visible in smaller inclusions (apparent Lc); clathrate melting reveals the presence of small water amounts. At room temperature, the fraction of the volatile phase (fvp) ranges from 90 to $100 \mathrm{vol} \%$. $\mathrm{Tm} \mathrm{CO} 2$ of these inclusions ranges from -60.0 to $-58.7^{\circ} \mathrm{C}$, Th $\mathrm{CO} 2(\mathrm{~L}+\mathrm{V} \rightarrow \mathrm{L})$ are identical for a given cluster and ranges from 10.3 to $12.5^{\circ} \mathrm{C}$. Tm cl ranges from 8.6 to $9.8^{\circ} \mathrm{C}$ and $\mathrm{Tm}$ ice from -7.1 to $-4.9^{\circ} \mathrm{C}$. Total homogenisation temperatures range from 289 to $312^{\circ} \mathrm{C}$.

In both $\mathrm{LC}-\mathrm{w}$ and $\mathrm{Lw}-\mathrm{C}, \mathrm{CO}_{2}$ predominates in the volatile phase (82 to $95 \mathrm{~mol} . \%$ ), the $\mathrm{CH}_{4}$ content ranging from 2 to $9 \mathrm{~mol} . \%$ and $\mathrm{N}_{2}$ from 6 to 9 mol.\%. In Lc-(w) inclusions, $\mathrm{N}_{2}$ ranges from 9 to 13 mol.\% (Table 2), and $\mathrm{CH}_{4}$ ranges from 2.7 to 3.7 mol.\%. Table 2 provides the main features of representative FI bulk compositions.

\section{Bulk chemical evolution}

Water is the main constituent of the aqueous-carbonic fluids (LC-w) from Qtz I and II. The partial resetting of the $\mathrm{FI}$ during deformation may explain variations in density and volatile/water ratio ranges shown in Fig. 11. In topaz II (Stage IIla), water-rich aqueous carbonic $\mathrm{FI}$ and volatile-rich liquids constitute two assemblages of $\mathrm{FI}$ characterised by high densities and well-defined chemical compositions. Both have a volatile component dominated by $\mathrm{CO}_{2}$ and a minor $\mathrm{CH}_{4}$ contribution, but differences in the $\mathrm{N}_{2}$ content (Fig. 12).

All fluid inclusions from I-II and III stages are aqueous-carbonic and have $\mathrm{H}_{2} \mathrm{O} / \mathrm{CO}_{2} / \mathrm{CH}_{4}$ ratio close to those predicted by water-graphite equilibrium at high temperatures above $400^{\circ} \mathrm{C}$ (Huizenga, 2001). The volatile phase, dominated by $\mathrm{CO}_{2}$, from both the $\mathrm{Lw}-\mathrm{C}$ and $\mathrm{LC}-\mathrm{w}$ inclusions, is coherent with the high P-T pair of trapping at water-graphite equilibrium, as discussed below. Thus, two trends are distinguished in the diagram $\mathrm{N}_{2} / \mathrm{CO}_{2}$ versus $\mathrm{CH}_{4} / \mathrm{CO}_{2}$ 
(Fig. 12): i) the first one at nearly constant $\mathrm{CH}_{4} / \mathrm{CO}_{2}$ is characterised by a broader range of $\mathrm{N} 2$ contents and corresponding to the volatile-rich fluid enriched in $\mathrm{N}_{2}$ and ii) the aqueous-carbonic fluids (Lc-w, $\mathrm{Lw}-\mathrm{C}$ ) with a $\mathrm{CH}_{4} / \mathrm{CO}_{2}$ ratio ranging from 0.05 to 0.10 . Fig. 11 and 12 emphasise the similarities between Lc- $(\mathrm{w})$ and $(\mathrm{Lw}-\mathrm{c}) \mathrm{FI}$, distinctively of Lc-w FI. The Lc-w inclusions are slightly richer in $\mathrm{N}_{2}$, e.g., a gas produced by the oxidation of ammonium released by micas or feldspars alteration or melting.

\section{Interpretation and discussion}

\subsection{P-T estimation}

A series of isochores representative of the different fluid types calculated from microthermometric and Raman spectroscopy measurements are reported on a pressuretemperature plot together with thermal gradients (Fig. 13). The dense volatile-rich carbonic fluids Lc-(w) trapped in topaz have rather flat isochores, sub-parallel to high thermal lithostatic gradients between 50 and $60^{\circ} \mathrm{C} / \mathrm{km}$. The Lc-w inclusions show much steeper isochores. As Lc-(w) and LC-w are trapped in the same clear topaz II and considered as sub-synchronous of the same event, the intersection of their isochores provides the best estimates of their trapping conditions. The resulting P-T box $480-520^{\circ} \mathrm{C}$ range, and $230-270 \mathrm{MPa}$, is inferred for the topaz stage, i.e., slightly below P-T conditions (300-350 MPa, 500-550 ${ }^{\circ} \mathrm{C}$ ) estimated for contact metamorphism developed by late to post-tectonic granites in northern Portugal (Guedes et al., 2002, Noronha et al., 1999, Vallance et al., 2003).

The presence of both Lc-(w) and Lc-w fluids, one dominated by volatiles and the other by water could be at first glance interpreted as the product of unmixing. The unmixing is, however, highly improbable considering the P-T estimates above mentioned, which are far from the isopleth in the $\mathrm{H}_{2} \mathrm{O}-\mathrm{CO}_{2}-\mathrm{NaCl}$ system. The conditions of unmixing along the isopleth or under lower $\mathrm{P}-\mathrm{T}$ pairs (two-phase field) in the system $\mathrm{H}_{2} \mathrm{O}-\mathrm{CO}_{2}-\mathrm{NaCl}$, and for salinities around 6 wt $\% \mathrm{NaCl}$ equiv. (Weisbrod, 1984, Diamond, 2003), are: i) at 200-250 MPa, around 250 to $330^{\circ} \mathrm{C}$, e.g. approximately 100 to $150^{\circ} \mathrm{C}$ below the inferred temperature, and ii) at $500^{\circ} \mathrm{C}$, about $60 \mathrm{MPa}$, thus 150 to $200 \mathrm{MPa}$ below the inferred pressure. Therefore, the unmixing of the volatile phase from a parent aqueous-carbonic fluid can be precluded.

The presence of volatile dominated Lc-(w) fluids and aqueous-carbonic Lc-w fluids can be alternately interpreted as fluids generated at two distinct higher temperatures, at equilibrium with graphite. The consideration of the fluid compositions in the $\mathrm{C}-\mathrm{H}-\mathrm{O}-(\mathrm{N})$ system in equilibrium with graphite can be used to estimate the P-T conditions along which the fluid composition evolved (Huizenga and Touret, 1999; Huizenga, 2001). Redox conditions need first to be evaluated. Oxygen fugacity ( $\mathrm{fO}_{2}$ ) values near the quartz-fayalite-magnetite (QFM) redox equilibrium is a reasonable assumption for either high-grade metamorphic rocks or lowgrade graphite-bearing metasediments (Ohmoto and Kerrick, 1977; Lamb and Valley, 1984). 
Under these redox conditions, for the Lc-w fluid, a water content higher than 0.9 and $\mathrm{XCO}_{2} /\left(\mathrm{XCO}_{2}+\mathrm{XCH}_{4}\right)$ above 0.9 yield to P-T estimates around $450-470^{\circ} \mathrm{C}-220 \mathrm{MPa}$ or above, in agreement with the P-T domain issued for isochore intersection. For the Lc-(w) fluids, a temperature of $550^{\circ} \mathrm{C}$ and equilibrium water-graphite at QFM, is necessary to explain an $\mathrm{XCO}_{2} /$ $\left(\mathrm{XCO}_{2}+\mathrm{XH}_{2} \mathrm{O}+\mathrm{XCH}_{4}\right)$ reaching 0.9 , a temperature significantly higher than for $\mathrm{Lw}-\mathrm{C}$ fluids. Thus, the water content decreases drastically with increasing temperature above $500^{\circ} \mathrm{C}$ to values around 0.1 (Huizenga, 2001). At such temperature, $\mathrm{CH}_{4}$ is not supposed to be present, but traces of $\mathrm{CH}_{4}$ in the $\mathrm{Lc}$-(w) fluid could be related to subsequent contamination during fluid ascent and mixing process. The two main types of fluids could have been thus generated via similar processes and from similar pristine fluids but at two distinct temperatures. The lack of re-equilibration of the ascending Lc- $(w)$ fluids may be due to kinetics and velocity of the fluid ascent. $\mathrm{N}_{2}$ in the aqueous-carbonic fluids could find its origin in the release of nitrogen during fluid-rock interactions, either from micas or from feldspars where ammonium is substituted to potassium (Bebout and Fogel, 1992, Moine et al., 1994). $\mathrm{N}_{2}$ is thus rather abundant in fluids issued from migmatites. Graphite-saturated $\mathrm{CO}_{2}-\mathrm{N}_{2}$ fluid inclusions were found in migmatites formed from metapelites in western Carpathians (Hurai et al., 2000). Nitrogen found in dense carbonic liquids may be related to the oxidation of ammonium from micas or feldspars during fluid-rock interaction or partial melting at depth. $\mathrm{CO}_{2}-\mathrm{H}_{2} \mathrm{O}$ fluids were found in a variety of migmatites formed from metasedimentary sequences. For instance, migmatites from Terra Nova Bay developed under $35 \mathrm{MPa}$, and $700^{\circ} \mathrm{C}$ present such fluid types (Giorgetti et al., 1996). It is, therefore, reasonable to infer the existence of a migmatitic zone to produce a large volume of fluids similar to those encountered at Panasqueira.

Considering the few isochores available for the densest fluid inclusions from quartz Qtz I, a rough estimate of the Qtz I formation is around $430-500^{\circ} \mathrm{C}$ and $210-290 \mathrm{MPa}$. Pressure fluctuations may have occurred due to oscillations around lithostatic pressures. The structural level estimated for the topaz stage is around 8 to $10 \mathrm{~km}$ depth. Such a depth is not surprising when considering the whole CIZ. Noronha et al. $(1992,1999)$ proposed similar pressure for most other W deposits from northern Portugal. Pseudo-metamorphic fluids equilibrated with metamorphic rocks are recorded in most Au deposits from western Europe (Boiron et al., 1996, 2003) and found abundantly in As-Au deposits from the CIZ in north-Portugal and trapped as such pressures (Vallance et al., 2003). These high pressures and deep structural levels contribute to a new vision of the hydrothermal system at Panasqueira. Thus, unlike most previous works (references in the introduction) that followed Kelly and Rye's model of a magmatic-hydrothermal fluid system linked to a shallow granitic intrusion at a depth of less than $3 \mathrm{~km}$, the data obtained in the present work demonstrate that the $\mathrm{W}$-deposit results from non-magmatic fluids flowing at a depth of about 8-10 km. Such depth for Stages I-II and III is likely related to a period prior to exhumation. 
Taking into account the ages available at the beginning of the hydrothermal system dated by U-Pb on W-rich rutile (305.2 $\pm 5.7 \mathrm{Ma}$, Carocci et al., 2020) and cassiterite (303 to $301 \mathrm{Ma}$, Zhang et al., 2019), the most probable age for this period is 301-306 Ma..

\subsection{Wolframite and quartz-topaz deposition}

According to our findings, the main stage of $\mathrm{W}$ deposition was a quasi-monomineralic stage characterised first by the predominant deposition of wolframite at the fracture edges, and the sealing of the vein by quartz, as in most $\mathrm{W}$ deposits worldwide, such as the W-veins from the main Chinese W province (e.g., Liu et al., 2018). Topaz infilled specific fractures, and sometimes sphalerite and pyrrhotite end the infilling. During the topaz stage, two fluids are present: a dense volatile ( $\left.\mathrm{CO}_{2}\right)$-dominated liquid enriched in $\mathrm{N}_{2}$ and an aqueous-carbonic fluid. Both fluids may result from the equilibrium between water and graphite at different temperatures within the metamorphic series. They display similarities with the rare relics from stage I tungsten depositing fluids. Gibert et al. (1982) have shown by modelling that the addition of less than $10 \mathrm{~mol} . \% \mathrm{~N}_{2}$ to the mineralising fluids results in a marked increase in $\mathrm{H}_{2} \mathrm{WO}_{4}$ and $\mathrm{HWO}_{4}$ - concentrations relative to $\mathrm{WO}_{42}$ - and subsequently yield a significant decrease of $\mathrm{W}$-mineral solubility. Pulses of volatiles $\left(\mathrm{N}_{2}, \mathrm{CH}_{4}, \mathrm{CO}_{2}\right)$ affect the dielectric constant of water and favour subsequently W-mineral precipitation. Such a process accounts for the commonly observed association of W-deposits with graphitic series generating volatiles. The origin of nitrogen may either be related to the oxidation of ammonium contained by micas or feldspars within metamorphic series, or to the release of $\mathrm{N}_{2}$ during the partial melting of feldspars and micas in the migmatites at depth.

After wolframite deposition, pressure fluctuation produced by a fault-valve process (Sibson 1990, 2000) may finally explain the massive quartz deposition. This model was already proposed by Foxford et al. (2000), who considered the vein swarm as formed through extensional failure driven by hydraulic-valving. Quartz deposit is favoured at constant temperature by pressure drop-down consecutive to the failure, as quartz solubility decreases together with pressure decrease (Fournier, 1983). The formation of sulphides after topaz is more challenging to explain, in particular the sudden venue of $\mathrm{H} 2 \mathrm{~S}$ rich fluids enriched in $\mathrm{Zn}$ and probably Fe. This point will not be discussed here, having been cogently addressed by Kelly and Rye (1979).

\subsection{Deep-seated heat anomalies and fluid sources}

The P-T domain delineated by isochores suggests high thermal gradients of 50 to $60^{\circ} \mathrm{C} / \mathrm{km}$ (Fig. 13) which are higher than the regional $42^{\circ} \mathrm{C} / \mathrm{km}$ gradient for Upper Carboniferous (e.g. Ferreira et al., 2019). Besides, a part of the fluids (Lc-(w)) equilibrated with host metamorphic 
formations at a higher temperature than at the deposition level (Fig. 14). Therefore, heat advection was involved.

The main Panasqueira granite intruded the Beira schist before the inception of the hydrothermal system as the thermal aureole assemblages were obliterated by the early tourmalinisation (Carocci et al., 2020). It cannot, therefore, be the required heat source. Quartz-wolframite veins then intersected the later rare metal granite sequence found in the "Greisen cupola" (Marignac et al., 2020), indicating that granites could not be considered as a heat source either. However, the presence in the SW of the deposit of both the topaz rich ( \pm cassiterite) zone and the geophysical anomalies at close distance (Fig. 2) likely testify for the presence of concealed intrusions responsible for Sn and F inputs (Pinto et al., 2015). Such intrusions would be of too small volume and could have been at best only additional sources of heat.

On the other hand, high-temperature events are documented in the lower crust of the $\mathrm{CIZ}$ during all the Late Carboniferous (Orejana et al., 2011), implying the long-lasting possibility of heat advection by upward fluids transfer. Migmatites domes are known in several places in the $\mathrm{CIZ}$, in particular in the Spanish Central System, to the east of the Panasqueira area (Fig. 2). A first migmatisation event, yielding banded metatexites, was widespread and occurred at $\mathrm{c}$. $320 \mathrm{Ma}$ (e.g., Lopez-Moro et al., 2018). A second event, more localised in the core of D3 domes, was characterised by biotite dehydration melting yielding cordierite-bearing diatexites and occurred at c. 305-300 Ma (e.g., Diaz-Alvarado et al., 2013).

A migmatite domain from the second migmatisation event would, therefore, be a likely source of heat, and also of fluids, below the Panasqueira deposit as suggested by the schema from figure 14. Experimental and field data concur in showing that dehydration-melting "granitic" melts contain significant amounts of dissolved water, typically around $5 \mathrm{wt} \%$ at $750^{\circ} \mathrm{C}$ and 500 MPa (Le Breton and Thompson, 1988; Braga et al., 2010, Carvalho et al., 2019). Thus, as pointed out by Braga et al. (2010), migmatites produced in a continental collision zone will act as a sink of hydrous fluids as long as the crust is partially molten. Then, upon cooling and decompression towards subsolidus conditions, the fluid stored in the migmatitic leucosome will be released. Given the large volume of migmatite domains, they constitute therefore the most significant potential source of deep fluids in the crust, far more than granites.

Besides, as shown in the Ivrea zone, metapelitic migmatites formed through muscovite and biotite breakdown melting may produce $\mathrm{C}-\mathrm{O}-\mathrm{H}-\mathrm{N}$ fluids. The latter fluids are assumed to be internally derived by devolatilisation of hydrous silicates in the graphitic protolith, then as a result of oxidation of carbon by melting of Fe3+-bearing biotite (Carvalho et al., 2019). Such a process applies to the mechanisms of production of Panasqueira fluids.

\subsection{Mass and heat transfers from deep levels up to the Panasqueira level}


Panasqueira fluids had to travel from the deep-seated zones up to the deposition levels at the top of the Panasqueira granite, at about $10 \mathrm{~km}$ depth, e.g. close to the top of ductile-brittle transition zone which occurs around 10 to $16 \mathrm{~km}$ depth (Ingebritsen and Manning, 2010, LlanaFunez and Lopez-Fernandez, 2015).

Fluid circulation is possible in the deep crust. Large fluid quantities stored in the lower crust at peak metamorphic conditions are later expelled towards shallower crustal levels during retrogradation (Touret and Nijland, 2013). On the one hand, theoretical considerations show that permeability can be significantly enhanced. At depth in the ductile Earth's crust, permeability increases significantly, at strains as low as a few per cent, through microcrack growing and rapid development of connectivity in grain-scale crack networks. Thus, the pore fluid factor, which is the ratio of pore fluid pressure to vertical stress, is high enough to facilitate deformation by microcracking (Conolly, 1997; Cox, 2002). Indeed, in zones characterised generally by a permeability as low as $10-18-10-20 \mathrm{~m} 2$, permeable vertical cracks can efficiently transfer heat energy, magmas and fluids from the lower crust to the upper crust (Ingebritsen and Manning, 2010, Zhao et al., 2002). On the other hand, there is plenty of field evidence that metamorphic fluids may migrate towards deep shear zones where they are focused and may flow upward (e.g., Van Reenen et al., 1994, Kolb et al., 2004, Siebenaller et al., 2013, Rolland and Rossi, 2016, Dyja-Person et al., 2018).

In the Panasqueira case, there is no direct evidence for the existence of a drainage zone. Nevertheless, indirect evidence seems to testify for a permanent structure allowing recurrent transfers of fluids and magmas. First, the late-kinematic "Seixo Bravo" quartz veins which prove for metamorphic fluid circulation (Noronha et al., 1992) were only found within the Panasqueira area, where they form a subvertical cylindrical volume, suggestive of a deeprooted subvertical fluid pathway (Fig. 14). Field observations demonstrate that the Seixo-Bravo veins predated the Panasqueira granite emplacement (Noronha et al., 1992; Launay, 2018). Second, there is a need for a pathway for the magma, which resulted in the main Panasqueira granite laccolith emplacement. Feeding through vertical dykes is the commonly accepted way for such an emplacement (Petford et al., 2000) and indeed, geophysical modelling (Ribeiro, 2017) shows the existence of NE-SW root that may be related to such a dyke. Third, the recurrence of rare metal granite emplacement (Marignac et al., 2020) argues for the persistence of a weakness zone under the deposit, the more if effectively tin and fluor of stage III must be related to a new input of rare metal magma. Ascent of magmas are favored by a transpression zone of transcurrent shear, in particular in extensional segments of the associated strike-slip system (Brown, 1994, Brown, 2013). Finally, the isotopic ratio of helium $3 \mathrm{He} / 4 \mathrm{He}$ trapped in $\mathrm{FI}$ from wolframite (Burnard and Polya, 2004) is five times higher than the atmospheric ratio and, therefore, inconsistent with a peraluminous granite source. These authors thus interpret fluids as coming from a deeper source such as migmatites, or the mantle. 
This conclusion is a further argument for a deep-seated structure, similar to those demonstrated in the Great Basin (Nevada, USA) by Siler and Mack Kennedy (2016).

\section{5-5 Fault valve behaviour in the lower part of the seismogenic region}

Whereas fluid flow is continuous along actively creeping parts of shear networks, in contrast, at and above the seismic-aseismic transition, potentially significant, cyclic changes in fault permeability are associated with episodic rupture and interseismic fracture sealing (Cox, 2002). Such fracture development follows the classic fault-valve process (Sibson, 1994; Boullier and Robert, 1992, Kolb, 2008). It is in the lower regions of the seismogenic zone, i.e. around $10 \mathrm{~km}$ depth like at Panasqueira, that valve-action is the most effective (Sibson, 1992, 1994). There, large ruptures tend to nucleate as a consequence of fluid overpressure, as proposed for the Panasqueira vein system (Foxford et al., 2000). Fluctuation around lithostatic pressure during the topaz stage fits well with this model.

\section{Conclusion}

- The oxide stage at Panasqueira is a quasi-monomineralic stage characterised by the predominant deposition of wolframite at the fracture edges, and the sealing of the vein by quartz, as in most $\mathrm{W}$ deposits worldwide. The topaz stage occurs after $\mathrm{W}$ deposition during a stage characterised by the reopening of the boundary between the vein and wall rock or new fracture infilling crosscutting wolframite.

- At variance of Qtz I and Topaz I which underwent a deformation causing the almost complete loss of the primary fluid inclusions, the topaz II hosts high-density liquids either aqueouscarbonic or volatile-rich which indicate trapping conditions of $500 \pm 20^{\circ} \mathrm{C}$ and $240 \pm 20 \mathrm{MPa}$. Thus, unlike most previous works that followed Kelly and Rye's model of a magmatichydrothermal system linked to a shallow granitic intrusion (less than $3 \mathrm{~km}$ ), the data obtained in the present work demonstrate that the main fluids percolating the vein system at a depth of about 8-10 km, were non-magmatic, rooted at greater depth, and deeply equilibrated with metamorphic formations.

- the high thermal gradient in between 50 and $60^{\circ} \mathrm{C} / \mathrm{km}$, the successive granite intrusions including rare-metal granite acting as a source of $\mathrm{F}$ and $\mathrm{Sn}$, the previous formation of subvertical and deformed quartz veins (Seixo Bravo veins), the presence of fluids equilibrated at higher temperatures attest for a long-lived upward transport of magmas and fluids from the deeper crust. A hypothetic deep crustal shear zone, located below the deposit, is proposed to explain the upward circulation of waters possibly extracting tungsten from either the metamorphic series or previously crystallised granites or both. The wolframite and then the topaz deposition occurred probably when the structural level was at the basis of the 
615 seismogenic zone, thanks to fault-valve fracturing and sealing processes, at the beginning of 616 the exhumation of the CIZ belt, probably around 301-306 Ma.

\section{Acknowledgements}

619 This work was funded by the ERAMIN project NewOres funded by ANR (ANR-14-EMIN-0001), 620 and Labex Ressources 21 (supported by the French National Research Agency through the 621 national program "Investissements d'avenir") with reference ANR - 10 - LABX 21 — LABEX 622 RESSOURCES 21. The MicroXRF used is a piece of equipment co-funded by ICEEL (Carnot 623 institute)-CREGU-Labex Resources 21, Lorraine Région, and FEDER. We are most grateful 624 to Beralt Tin and Wolfram S.A. for permitting access to the Panasqueira underground mine. 625 Alfons van den Kerkhof and an anonymous reviewer are warmly thanked for their constructive 626 and pertinent comments which greatly helped to improve the manuscript. Scott Ashley is warmly thanked for his review of English spelling and grammar. 


\section{References}

Almonty Industries, 2016. Report NI 43-101. Technical report on the mineral resources and reserves of the Panasqueira mine, Portugal: http://www.almonty.com/_resources/Panasqueira_43101_Tech_Rep_Dec16_SEDAR.P DF.

Bakker, R. J., 1997. Clathrates: Computer programs to calculate fluid inclusion VX properties using clathrate melting temperatures. Computers \& Geosciences 23, 1-18.

Bakker, R. J., 1999. Adaptation of the Bowers and Helgeson (1983) equation of state to the $\mathrm{H}_{2} \mathrm{O}-\mathrm{CO}_{2}-\mathrm{CH}_{4}-\mathrm{N}_{2}-\mathrm{NaCl}$ system. Chem. Geol. 154, 225-236.

Bakker, R. J., 2003. Package FLUIDS 1. Computer programs for analysis of fluid inclusion data and for modelling bulk fluid properties. Chem. Geol. 194, 3-23.

Bebout, G. E., Fogel, M. L., 1992. Nitrogen-isotope compositions of metasedimentary rocks in the Catalina Schist, California; implications for metamorphic devolatilisation history. Geochim. Cosmochim. Acta 56, 2839-2849.

Bodnar, R. J., 2003. Introduction to fluid inclusions. In I. Samson, A. Anderson, \& D. Marshall, eds. Fluid Inclusions: Analysis and Interpretation. Mineral. Assoc. Canada, Short Course 32, 1-8.

Boiron, M.C., Essarraj, S., Sellier, E., Cathelineau, M., Lespinasse, M., Poty, B., 1992. Identification of fluid inclusions in relation to their host microstructural domains in quartz by cathodoluminescence. Geochim. Cosmochim. Acta 56, 175-185.

Boiron M.C., Cathelineau M., Banks D., Yardley B., Noronha F., 1996. P-T-X conditions of fluid penetration in the basement during retrograde metamorphism and uplipt: $A$ multidisciplinary investigation of bulk and individual fluid inclusion chemistry from NW iberian quartz veins. Geochim. Cosmochim. Acta 60, 43-57.

Boiron, M.C., Cathelineau, M., Banks, D.A., Fourcade, S., Vallance, J., 2003. Mixing of metamorphic and surficial fluids during the uplift of the Hercynian upper crust: consequences for gold deposition. Chem. Geol. 194, 119-141.

Boullier, A.M., Robert, F., 1992. Paleoseismic events recorded in Archean gold \pm quartz vein networks, Val d'Or, Abitibi, Quebec, Canada. J. Struct. Geol. 14, 161-179.

Bowers, T.S., Helgeson, H.C., 1983. Calculation of the thermodynamic and geochemical consequences of non-ideal mixing in the system $\mathrm{H}_{2} \mathrm{O}-\mathrm{CO}_{2}-\mathrm{NaCl}$ on phase relation in geological systems: equation of state for $\mathrm{H}_{2} \mathrm{O}-\mathrm{CO}_{2}-\mathrm{NaCl}$ fluids at high pressure and temperature. Geochim. Cosmochim. Acta 47, 1247-1275.

Braga, R., Massonne, H. J., Mazza, S., Bondi, M., 2010. High-pressure migmatites as source of fluids during subduction and crustal thickening: the case of the Ulten Zone. Geophysical Research Abstracts Vol. 12, EGU2010-5838-2. 
Brown, M., 1994. The generation, segregation, ascent and emplacement of granite magma: the migmatite-to-crustally-derived granite connection in thickened orogens, Earth-Sci. Rev. 36, 83-130.

Brown, M., 2013. Granite: From genesis to emplacement. GSA Bulletin 125, 7/8, 1079-1113. Burnard, P.G., Polya, D.A., 2004. Importance of mantle derived fluids during granite associated hydrothermal circulation: $\mathrm{He}$ and $\mathrm{Ar}$ isotopes of ore minerals from Panasqueira. Geochim. Cosmochim. Acta 68, 1607-1615.

Bussink R. W., 1984. Geochemistry of the Panasqueira tungsten-tin deposit, Portugal. Geol. Ultraiectina 33, 170p.

Bussink, R. W., Kreulen, R., de Jong, A. F., 1984. Gas analyses, fluid inclusions and stable isotopes of the Panasqueira W-Sn deposits, Portugal. Bull Min. 107, 703-713.

Campbell, A., Robinson-Cook, S., Amindyas, C., 1988. Observation of fluid inclusions in wolframite from Panasqueira, Portugal. Bull. Miner. 111, 251-256.

Carocci, E., 2019. Tungsten transport and deposition in magmatic-hydrothermal environments: the example of Panasqueira, (Portugal). Unpublished thesis, Univ. de Lorraine, $271 \mathrm{p}$.

Carocci, E., Marignac, C., Cathelineau, M., Boiron, M-C, Pinto, F., 2018. Le stade initial du dépôt de la wolframite dans le gisement à W-Sn-Cu de Panasqueira (Portugal) : Caractérisation indirecte des fluides par l'étude des tourmalines précoces. RST Lille, Oct 2018.

Carocci, E., Marignac, C., Cathelineau, M., Truche, L., Lecomte, A., Pinto, F., 2019. Rutile from Panasqueira (Central Portugal): an excellent pathfinder for wolframite deposition. Minerals 9, 9.

Carocci, E., Marignac, C., Cathelineau, M., Truche, L., Poujol, M., Boiron, M.C., Pinto F., 2020. Incipient wolframite deposition at Panasqueira (Portugal): W-rutile and tourmaline compositions as proxies for the early fluid composition. Econ. Geol., in press.

Carta Geológica (Geological map of Portugal) de Portugal a escala 1:1 000 000, 2010. LNEG-LGM, Lisboa, ISBN: 978-989-675-005-3.

Carvalho, B. B., Bartoli, O., Ferri, F., Cesare, B., Ferrero, S; Remusat, L., Capizzi, L., Poli, S., 2019. Anatexis and fluid regime of the deep continental crust: new clues from melt and fluid inclusions in metapelitic migmatites from Ivrea Zone (NW Italy). J. Metam. Petrol. 37, 951-975.

Cathelineau, M., Marignac, C., Rolland, J-M., Boiron, M-C., Dejean, M., Carocci, E., 2017. Are we sure to know the fluids responsible for $\mathrm{W}$ mineralisation at Panasqueira (Portugal) ? The case for loss of information due to intense quartz recrystallisation and FI natural decrepitation. S3.T16. ECROFI XXIV, Nancy. 
Codeço, M.S., Weis P., Trumbull R.B., Glodny J., Wiedenbeck M., Romer R.L., 2019. Boron isotope muscovite-tourmaline geothermometry indicates fluid cooling during magmatichydrothermal W-Sn ore formation. Econ. Geol. 114, 153-163.

Codeço, M.S., Weis, P., Trumbull, R.B., Pinto, F., Lecumberri-Sanchez, P., Wilke, F.D.H., 2017. Chemical and boron isotopic composition of hydrothermal tourmaline from the Panasqueira W-Sn-Cu deposit, Portugal. Chem. Geol. 468, 1-16.

Connolly, J. A. D., 1997, Devolatilisation-generated fluid pressure and deformationpropagated fluid flow during prograde regional metamorphism. J. Geoph. Res. Solid Earth 102, B8, 18,149-18,173.

Cox, S. F., 2002. Fluid flow in mid- to deep crustal shear systems: Experimental constraints, observations on exhumed high fluid flux shear systems, and implications for seismogenic processes. Earth Planets Space 54, 1121-1125.

Diamond, L. W., 2003. Introduction to gas-bearing, aqueous fluid inclusions. Fluid inclusions: analysis and interpretation. Mineralogical Association of Canada 32, 101-158.

Dias, G., Leterrier, J., Mendes, A., Simões, P.P., and Bertrand J.M., 1998. U-Pb zircon and monazite geochronology of post-collisional Hercynian granitoids from the Central Iberian Zone (Northern Portugal). Lithos 45, 349-369.

Díaz-Alvarado J, Fernández C, Castro A, Moreno-Ventas I., 2013. SHRIMP U-Pb zircon geochronology and thermal modeling of multilayer granitoid intrusions. Implications for the building and thermal evolution of the Central System batholith, Iberian Massif, Spain. Lithos 175-176, 104-123

Díez-Fernández, R., Arenas, R., Pereira, M.F., Sánchez-Martínez, S., Albert, R., Martin Parra, L.M., Rubio-Pascual, F.J., Matas, J., 2016. Tectonic evolution of Variscan Iberia: Gondwana-Laurussia collision revisited. Earth-Sci. Rev. 162, 269-292.

Díez-Fernández, R., Barreiro, J.G., Martínez-Catalán, J.R., Ayarza, P., 2013. Crustal thickening and attenuation as revealed by regional fold interference patterns: Ciudad Rodrigo basement area (Salamanca, Spain). J. Struct. Geol. 46, 115-128.

Díez-Fernández, R., Pereira, M.F., 2017. Strike-slip shear zones of the Iberian Massif: Are they coeval? Lithosphere 9, 726-744.

Duan, Z., Moller, N., Weare, J.H., 1996. A general equation of state for supercritical fluid mixtures and molecular dynamics simulation of mixture PVTX properties. Geochim. Cosmochim. Acta 60, 1209-1216.

Dubessy, J., Poty, B., Ramboz, C., 1989. Advances in COHNS fluid geochemistry based on micro-Raman spectrometric analysis of fluid inclusions. Eur. J. Mineral. 1, 517-534.

Dyja-Person, V., Tarantola, A., Richard, A., Hibsch, C., Siebenaller, L., Boiron M.C., Cathelineau, M., Boulvais, P., 2018. Metamorphic brines and no surficial fluids trapped in 
the detachment footwall of a Metamorphic Core Complex (Nevado-Filábride units, Betics, Spain). Tectonophysics 727, 56-72.

Fernández-Suárez, J., G. Gutiérrez-Alonso, S. T. Johnston, T. E. Jeffries, D. Pastor-Galan, G. A. Jenner, Murphy, J.B., 2011. Iberian late- Variscan granitoids: Some considerations on crustal sources and the significance of "mantle extraction ages". Lithos 123, 121-132.

Ferreira, J., dos Santos, T.B., Pereira, I., Mata, J., 2019. Exhumation and cooling rates of Variscan granites in an anatectic complex of the Central Iberian Zone, Portugal: constraints from LA- ICP-MS Zircon and Apatite U-Pb ages. Geophysical Research Abstracts . 2019, Vol. 21, p1-1.

Fournier, R.O., 1983. A method of calculating quartz solubilities in aqueous sodium chloride solutions, Geochim. Cosmochim. Acta. 47, 579-586.

Foxford, K., Nicholson, R., Polya, D., Hebblethwaite, R.P., 2000. Extensional failure and hydraulic valving at Minas da Panasqueira, Portugal: evidence from vein spatial distributions, displacements and geometries. J. Struct. Geol. 22, 1065-1086.

Gibert, F., Moine, B., Schott, J., Dandurand, J.L., 1992. Modeling of the transport and deposition of tungsten in the scheelite -bearing calc-silicate gneisses of the Montagne Noire, France. Contrib. Mineral. Petr. 112, 371-384.

Giorgetti, G., Frezzotti, M.L.E., Palmeri, R, Burke, E.A.J., 1996. Role of fluids in migmatites $\mathrm{CO}_{2}-\mathrm{H}_{2} \mathrm{O}$ fluid inclusions in leucosomes from the deep-freeze range migmatites (TerraNova Bay, Antarctica). J. Metamorph. Geol. 14, 307-317.

Guedes, A., Noronha, F., Boiron, M.C., Banks, D. A., 2002. Evolution of fluids associated with metasedimentary sequences from Chaves - North Portugal, Chem. Geol. 190, 273289.

Huizenga, J. M., 2001. Thermodynamic modelling of C-O-H fluids. Lithos 55, 101-114.

Huizenga, J.M., Touret, J.L.R., 1999. Fluid inclusions in shear zones: The case of the Umwindsi shear zone in the Harare-Shamva-Bindura greenstone belt, NE Zimbabwe. Eur. J. Mineral. 11, 1079-1090.

Hurai, V., Janák, M., Ludhová, L., Horn, E.E., Thomas, R., Majzlan J., 2000. Nitrogenbearing fluids, brines and carbonate liquids in Variscan migmatites of the Tatra Mountains, Western Carpathians - heritage of high-pressure metamorphism. Eur. Jour. Miner. 12, 1283-1300

Ingebritsen, S.E., Manning, C.E., 2010, Permeability of the continental crust: dynamic variations inferred from seismicity and metamorphism. Geofluids 10,193-205.

Jacques, D., Vieira, R., Muchez, P., Sintubin, M., 2017. Transpressional folding and associated cross-fold jointing controlling the geometry of post-orogenic vein-type W-Sn mineralisation: examples from Minas da Panasqueira, Portugal. Min. Dep. 53,171-194 
Jaques, L., Pascal, C., 2017. Full paleostress tensor reconstruction using quartz veins of Panasqueira Mine, central Portugal; part I: Paleopressure determination. J. Struct. Geol. 102, 58-74.

Kelly, W. C., Rye, R. O., 1979. Geologic, fluid inclusions, and stable isotope studies of the tin tungsten deposits of Panasqueira, Portugal. Econ. Geol. 74, 1721-1822.

Kolb, J., 2008. The role of fluids in partitioning brittle deformation and ductile creep in auriferous shear zones between 500 and $700^{\circ} \mathrm{C}$. Tectonophysics 446,1-15.

Kolb, J., Rogers, A., Meyer, F. M., Vennemann, T. W., 2004. Development of fluid conduits in the auriferous shear zones of the Hutti Gold Mine, India: evidence for spatially and temporally heterogeneous fluid flow. Tectonophysics $378,65-84$.

Lamb, W., Valley, J.W., 1984. Metamorphism of reduced granulites in low- $\mathrm{CO}_{2}$ vapour-free environment. Nature 312, 56-58.

Launay, G., 2018 Hydrodynamique des systèmes minéralisés péri-granitiques : étude du gisement à W-Sn-(Cu) de Panasqueira (Portugal) PhD thesis Orléans Univ., 506 p.

Launay, G., Sizaret, S., Guillou-Frottier, L., Gloaguen, E., Pinto, F., 2018. Deciphering fluid flow at the magmatic-hydrothermal transition: $A$ case study from the world-class Panasqueira W-Sn-(Cu) ore deposit (Portugal). Earth Planet. Sc. Lett. 499, 1-12.

Le Breton, N., Thompson, A. B., 1988. Fluid-absent (dehydration) melting of biotite in metapelites in the early stages of crustal anataxis. Contrib. Mineral. Petrol. 99, 226-237.

Lecumberri-Sanchez, P., Vieira, R., Heinrich, C.A., Pinto, F., Wälle, M., 2017. Fluid-rock interaction is decisive for the formation of tungsten deposits. Geology 45, 579-582.

Liu, X., Ma, Y., Xing, H., Zhang, D., 2018. Chemical responses to hydraulic fracturing and wolframite precipitation in the vein-type tungsten deposits of southern China. Ore Geol. Rev. 102, 44-58.

Llana-Funez , S., Lopez-Fernandez, C., 2015. The seismogenic zone of the continental crust in Northwest lberia and its relation to crustal structure. Tectonics 34, 1751-1767.

López-Moro, F.J., López-Plaza, M., Gutiérrez-Alonso, A., Fernández-Suárez, J., LópezCarmona, A., Hofmann, M., Romer, R.L., 2018. Crustal melting and recycling: geochronology and sources of Variscan syn-kinematic anatectic granitoids of the Tormes Dome (Central Iberian Zone). A U-Pb LA-ICP-MS study. Int. J. Earth Sci. 107, 985-1004 Lourenço, A., 2002. Paleofluidos e mineralizações associadas às fases tardias da Orogenia Hercínica. Unpupblished Thesis, Porto Univ., 303p.

Lüders, V., 1996. Contribution of infrared microscopy to fluid inclusion studies in some opaque minerals (wolframite, stibnite, bournonite); metallogenic implications. Econ. Geol. 91, 1462-1468.

Marignac, C., Cuney, M., Cathelineau, M., Lecomte, A., Carocci, E., Pinto, F., 2020. The Panasqueira rare metal granite suites and their involvement in the genesis of the world- 
class Panasqueira W-Sn-Cu vein deposit: a petrographic, mineralogical and geochemical study. Minerals 10, 562.

Mateus, A., Noronha, F., 2010. Sistemas mineralizantes epigenéticos na Zona CentroIbérica; expressão da estruturacão orogénica meso- a tardi-varisca (Epigenetic oreforming systems in Central-lberian Zone; products of an evolving orogenic framework in meso- to late-Variscan times). Ciencias Geológicas, Ensino, Investigacão e sua História (Geologia Aplicada), 2, 47-61.

Mateus, A., Figueras, J., Martins, I., Rodrigues, P.C., Pinto, F., 2020. Relative abundance and compositional variation of silicates, oxides and phosphates in the W-Sn-rich lodes of the Panasqueira Mine (Portugal): Implications for the ore-forming process. Minerals 10 , 551.

Moine, B., Guillot, C., Gibert, F., 1994. Controls of the composition of nitrogen-rich fluids originating from reaction with graphite and ammonium-bearing biotite. Geochim. Cosmochim. Acta 58, 5503-5523.

Noronha, F., Doria, A., Dubessy, J., Charoy, B., 1992. Characterisation and timing of the different types of fluids present in the barren ore-veins of the W-Sn deposit of Panasqueira, Central Portugal. Min. Dep. 27, 72 - 79.

Noronha, F., Vindel, E., Lopez, J.A., Garcia, E., Boiron, M.C., Cathelineau, M., 1999. Fluids related to tungsten ore deposits in northern Portugal and Spanish central system: a comparative study. Rev. Soc. Geol. Espana 12, 397 - 403.

Ohmoto, H., Kerrick D., 1977. Devolatilization equilibria in graphitic systems. Am. J. Sci. 277, 1013-1044.

Orejana, D., Villaseca, C., Armstrong, A., Jeffries, T.E., 2011. Geochronology and trace element chemistry of zircon and garnet from granulite xenoliths: Constraints on the tectonothermal evolution of the lower crust under central Spain. Lithos 124 , 103-116.

Pereira-Gómez, M.D., Rodriguez-Alonso, M.D., 2000. Duality of cordierite granites related to melt-restite segregation in the Peña Negra anatectic complex, central Spain. Can. Miner. $38,1329-1346$.

Pereira, M.F., Díez-Fernández, R., Gama, C., Hofmann, M., Gartner, A., Linnemann, U., 2017. S-type granite generation and emplacement during a regional switch from extensional to contractional deformation (Central lberian Zone, Iberian autochthonous domain, Variscan Orogeny). International J. Earth Sci.107, 251-267.

Petford, N., Cruden, A.R., McCaffrey, K.J.W., Vigneresse, J.L., 2000. Granite magma formation, transport and emplacement in the Earth's crust. Nature 408, 669-673.

Pinto, F., Vieira, R., Noronha, F., 2015. Different cassiterite generations at the Panasqueira Deposit (Portugal): Implications for the metal zonation model. Mineral Resources in a 
Sustainable World; André-Mayer, A.S., Cathelineau, M., Muchez, P., Pirard, E., Sindern, S., Eds, 827-830.

Polya, D. A., Foxford K. A., Stuart F. M., Boyce A., Fallick A. E., 2000. Evolution and paragenetic context of low $\delta \mathrm{D}$ hydrothermal fluids from the Panasqueira W-Sn deposit, Portugal; new evidence from microthermometric, stable isotope, noble gas and halogen analyses of primary fluid inclusions. Geochim. Cosmochim. Acta 64, 3357-3371.

Polya D.A., 1989. Chemistry of the main-stage ore-forming fluids of the Panasqueira W$\mathrm{Cu}(\mathrm{Ag})$-Sn deposit, Portugal: Implications for models of ore genesis. Econ. Geol. 84, 1134-1152

Ribeiro, R.F., 2017. Gravimetric Modelling and Geological Interpretation of ArgemelaPanasqueira Area. PhD Thesis, Porto Universidad, $61 \mathrm{p}$.

Roedder, E., 1979. Fluid inclusions as samples of ore fluids. In: Barnes, H.L (Ed), Geochemistry of Hydrothermal Ore Deposits, 2nd ed. Wiley, New-York, 984 - 737.

Rolland, Y., Rossi, M., 2016. Two-stage fluid flow and element transfers in shear zones during collision burial-exhumation cycle: Insights from the Mont Blanc Crystalline Massif (Western Alps). J. Geodyn. 101,88-108.

Rubio-Pascual, F.J., Arenas, R., Martínez-Catalán, J.R., Rodríguez-Fernández, L.R., Wijbrans, J.R., 2013. Thickening and exhumation of the Variscan roots in the Iberian Central System: Tectonothermal processes and 40Ar/39Ar ages. Tectonophysics 587, 207-221.

Sant'Ovaia, H., Olivier, P., Ferreira, N., Noronha, F., Leblanc, D., 2010. Magmatic structures and kinematics emplacement of the Variscan granites from Central Portugal (Serra da Estrela and Castro Daire areas). J. Struct. Geol. 32, 1450-1465.

Sibson, R.H., 1990. Conditions for fault-valve behaviour. Geol. Soc. Lond. Spec. Publ. 54, 15-28.

Sibson, R.H., 1992. Implications of fault-valve behaviour for rupture nucleation and recurrence. Tectonophysics, 211, 283-93.

Sibson, R.H., 1994. Crustal Stress, faulting and fluid flow. In: Parnell, J. (Ed.), Geofluids: Origin, Migration and Evolution of Fluids in Sedimentary Basins, Geological Society Special Publication, 78, pp. 69-84.

Sibson, R. H., 2000. Fluid involvement in normal faulting. J. Geodyn. 29, 469-499.

Siebenaller, L., Boiron, M.C., Vanderhaeghe, O., Hibsch, C., Jessell, M., France-Lanord, C., André-Mayer, A.S., Photiades, A., 2013, Fluid inclusion record in rocks exhumed through the ductile/brittle transition (Naxos Island, Cyclades, Greece). J. Metamorph. Geol. 31, 313-338.

Siler, D. L., Mack Kennedy, B. 2016. Regional crustal-scale structures as conduits for deep geothermal upflow. Geothermics 59, 27-37. 
Thiéry, R., Van Den Kerkhof, A. M., Dubessy, J., 1994. vX properties of $\mathrm{CH}_{4}-\mathrm{CO}_{2}$ and $\mathrm{CO}_{2}-$ $\mathrm{N}_{2}$ fluid inclusions: modelling for $\mathrm{T}<31^{\circ} \mathrm{C}$ and $\mathrm{P}<400$ bars. Eur. J. Mineral. 6, 753-771.

Touret, J. L. R., Nijland, T. G., 2013. Prograde, peak and retrograde metamorphic fluids and associated metasomatism in upper amphibolite to granulite facies transition zones. In: Harlov D.E., Austrheim H. (eds), Metasomatism and the chemical transformation of rocks, Springer, 415-469

Vallance, J., Cathelineau, M., Boiron, M. C., Fourcade, S., Shepherd, T. J., Naden, J., 2003. Fluid-rock interactions and the role of late Hercynian aplite intrusion in the genesis of the Castromil gold deposit, northern Portugal. Chem. Geol. 194, 201-224.

Van Reenen, D.D., Pretorius, A. I., Roering, C., 1994. Characterisation of fluids associated with gold mineralisation and with regional high-temperature retrogression of granulites in the Limpopo belt, South Africa. Geochim. Cosmochim. Acta 58,1147-1159.

Vigne, J-L., André, G., Kapal, F., 2018. Données industrielles, économiques, géographiques sur les principaux produits chimiques, métaux, matériaux (11ème edition). http://www.societechimiquedefrance.fr/extras/Donnees/acc.htm

Vityk, M. O., Bodnar, R. J., 1995. Textural evolution of synthetic fluid inclusions in quartz during reequilibration, with applications to tectonic reconstruction. Contr. Miner. Petr. 121, 309-323.

Weisbrod, A., 1984. Utilisation des inclusions fluides en géothermométrie, in Lagache M. ed., Thermométrie et Barométrie Géologiques. Soc. Fr. Min. Cristal. 2, 416-481.

Zhang, R., Ramos, V, Leal, S., Noronha F., Pinto F., 2019. U-Pb geochronology of cassiterites from primary Sn mineralisations in Sn-W Variscan Metallogenic Province, Portugal, Proc. 15th Biennal SGA Meeting, Glasgow, 357-360.

Zhao, C. Z., Hobbs, B. E., Mühlhaus, H. B., Ord, A., Lin, G., 2002. Analysis of steady-state heat transfer through mid-crustal vertical cracks with upward throughflow in hydrothermal systems. Int. J. Numer. Anal. Met. 26, 1477-1491. 

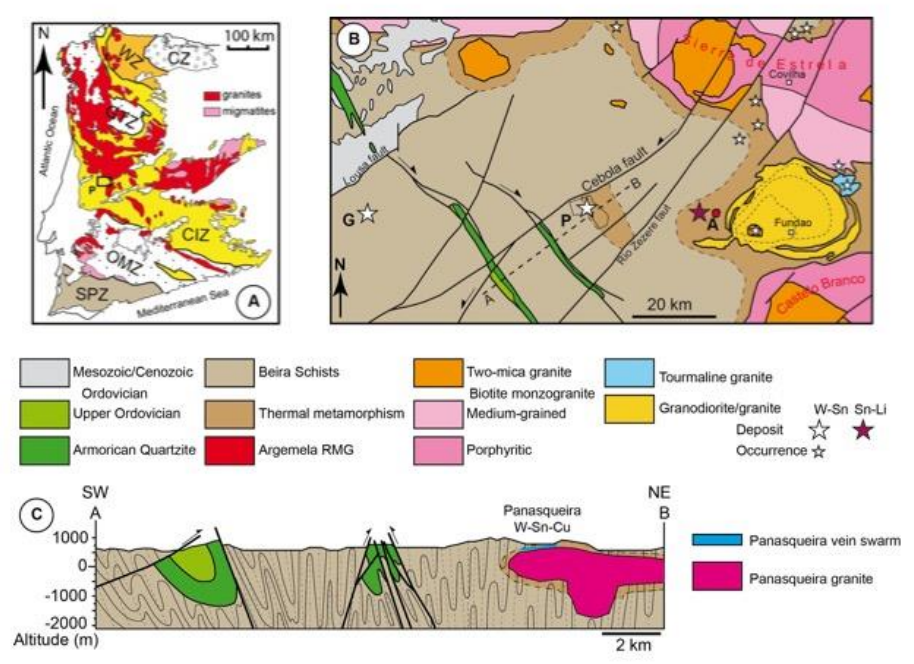

Fig. 1

Fig. 1: A) Simplified geological map of the Variscan Iberian massif with the location of the Panasqueira deposit district (noted P) within the CIZ (Central Iberian Zone), granites, and migmatites, WZ: West Asturian Leonese Zone, OMZ: Ossa Morena Zone, SPZ: South Portuguese Zone; B) Regional geological map with indication of the underground mine (star P), the contact metamorphic aureole (brown) and regional geological outcropping granites. A: Argemela granite, G: Gois W-showing (data source: Beralt Tin \& Wolfram S.A., Jaques and Pascal, 2017, Jacques et al., 2017, a geological map of Portugal at 1/ 1000000 (Carta geologica de Portugal, 2016); C: crosssection (dashed line A-B from map B) with the indication of the Panasqueira laccolith, Panasqueira vein swarm, and location of the remaining quartzites above the Beira schist formation. (figure slightly modified from Marignac et al., 2020) 


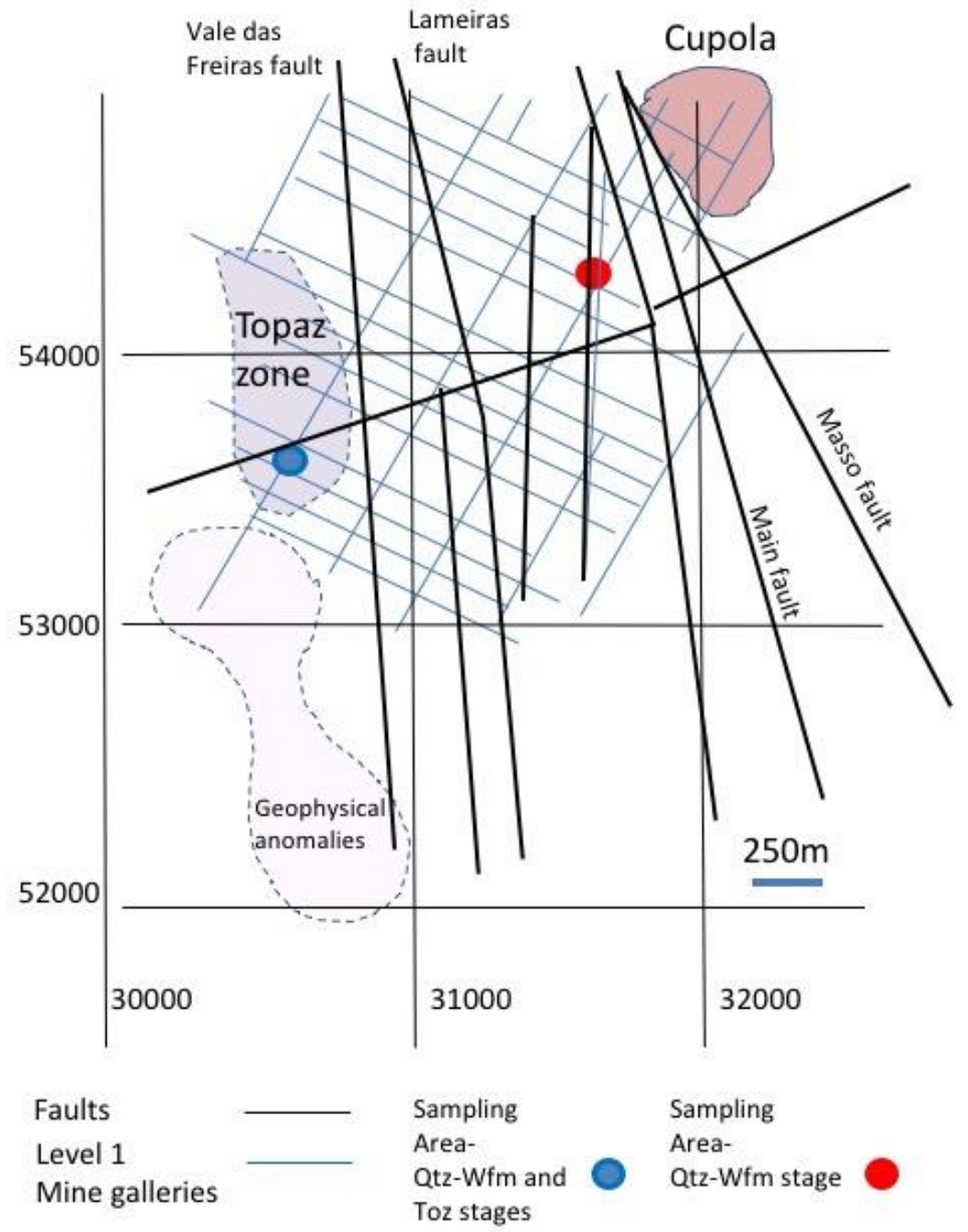

Fig. 2

Fig. 2: Mine works at Panasqueira (plan view) with an indication of a granite cupola outcropping at depth in mine galleries, as well as inferred granite bodies from geophysics. Samples are coming from two main zones: the "topaz zone" in light purple (blue point for sampling zone) and the "bank" at level 1 (red point) considered as one of the richest zones in W of the deposit. Qtz: quartz, Toz: topaz, Wfm: wolframite. 


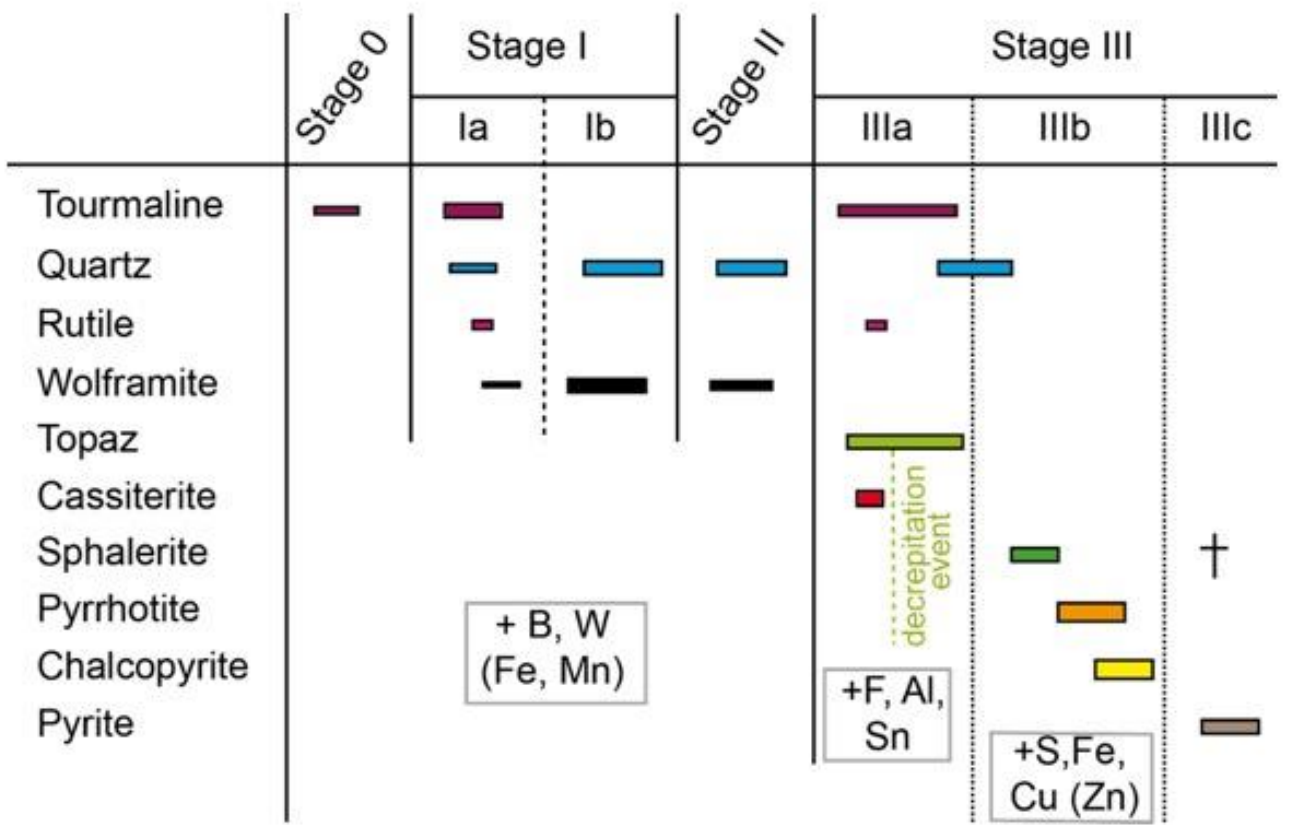

Fig. 3

Fig. 3: Paragenetic sequence of the main stages of W deposition (Stage I-II) and topazsulphides (stage III). The main element associations are indicated in the boxes. 

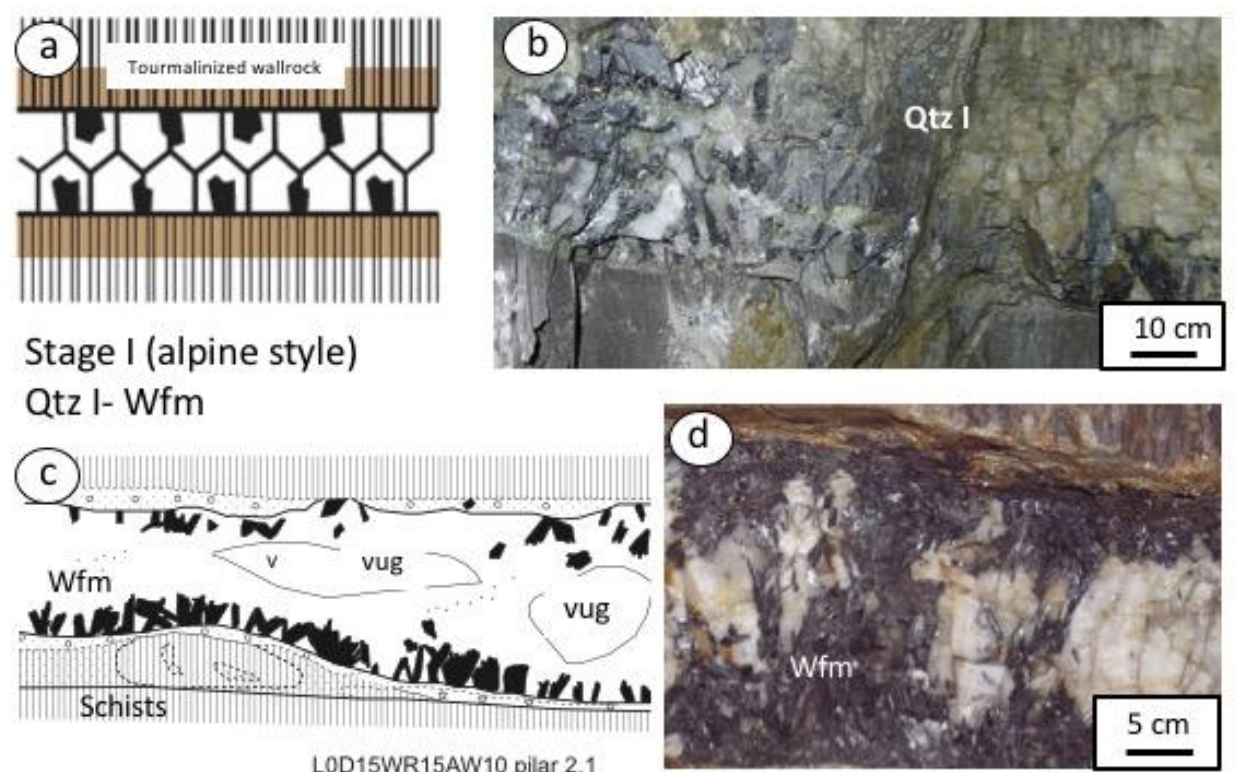

LOD15WR15AW10 pilar 2.1
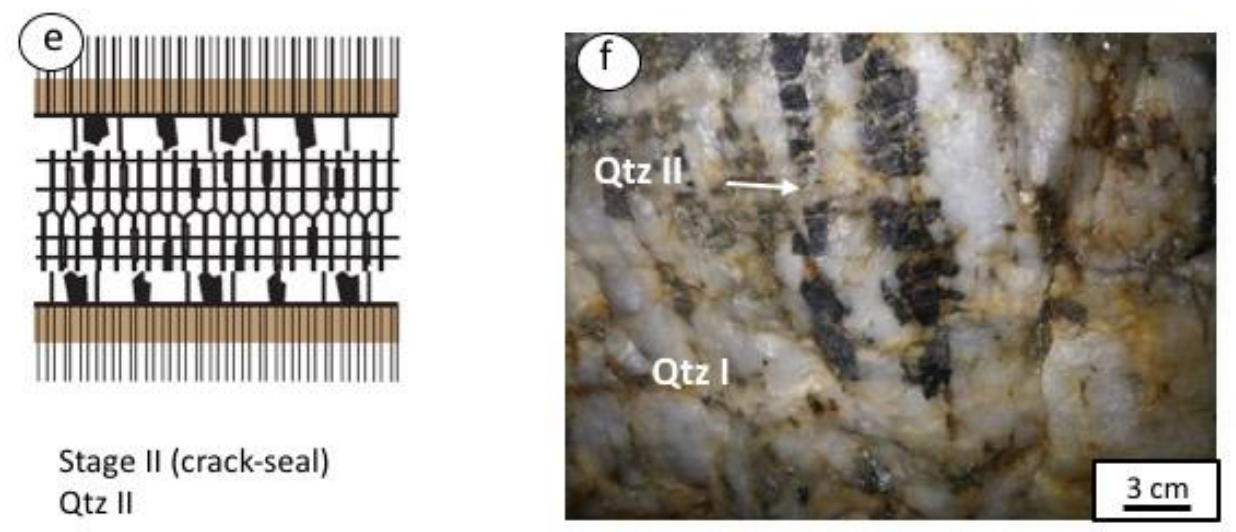

Stage II (crack-seal)

Qtz II

$3 \mathrm{~cm}$

Fig. 4

Fig. 4: Schematic drawings and photographs taken in mine galleries illustrating the stage I-II quartz-wolframite veins. Wall rocks are affected by tourmalinisation (a), and euhedral wolframite is crystallised along the vein edges and was followed by massive quartz precipitation, as shown in b, c, and d. Stage II is characterised by the deformation of quartz I and wolframite, and crack seal fracturing with Qtz II crystallisation (e-f). Qtz: quartz, Wfm: wolframite. 

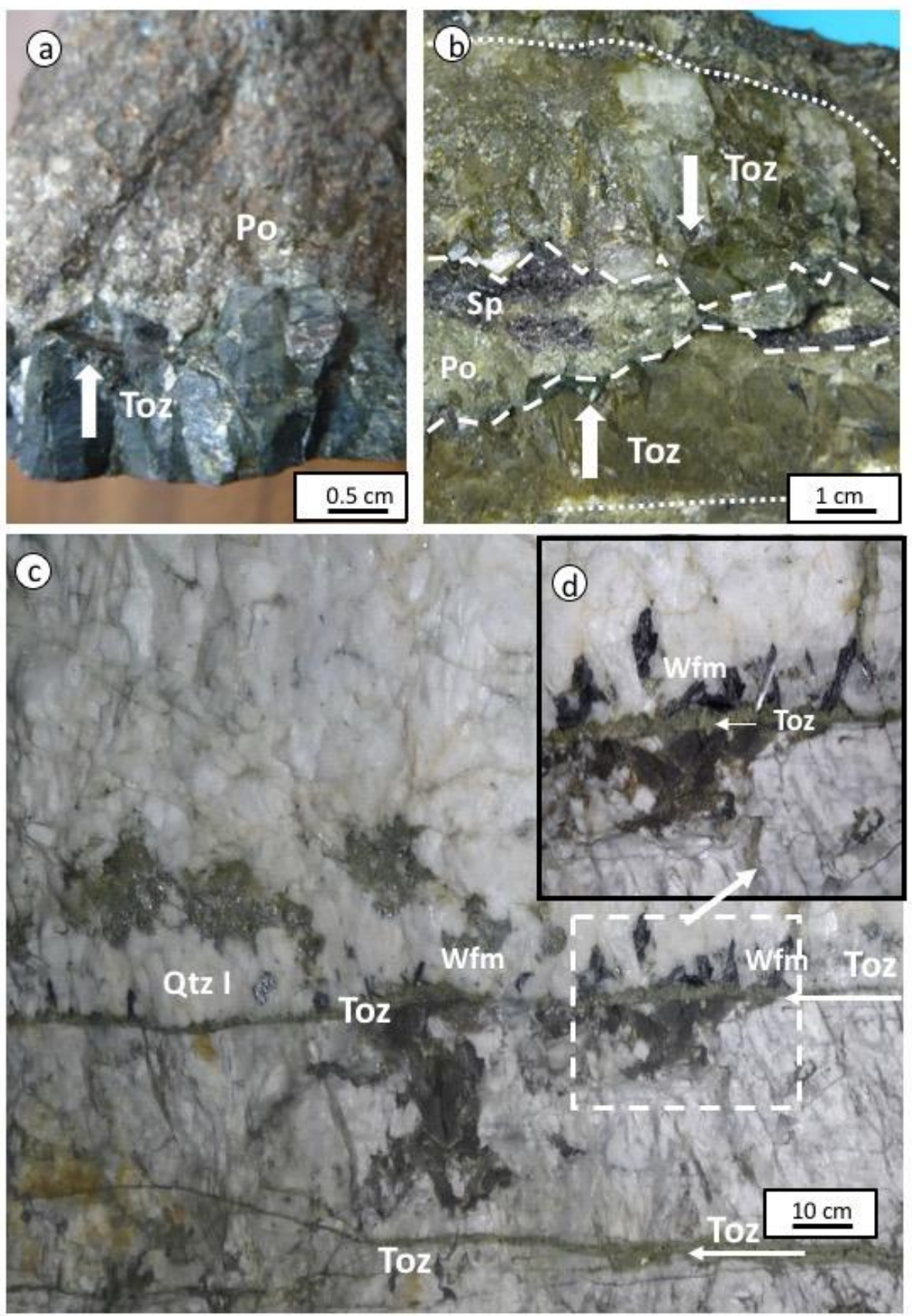

Fig. 5

940 Fig. 5: Photographs of the topaz veins: a) Euhedral topaz (Toz) vein along vein edges with pyrrhotite 941 (Po) infilling in the centre of the vein, white arrows indicate the direction of crystallisation, b) Topaz vein 942 with late sphalerite (Sp)-pyrrhotite infilling in the middle of the vein, $c$ ) Thin topaz veins crosscutting the early assemblage (quartz-wolframite from Stage I-II). d) inset from c) shows a detail of the relationships between topaz and wolframite. 


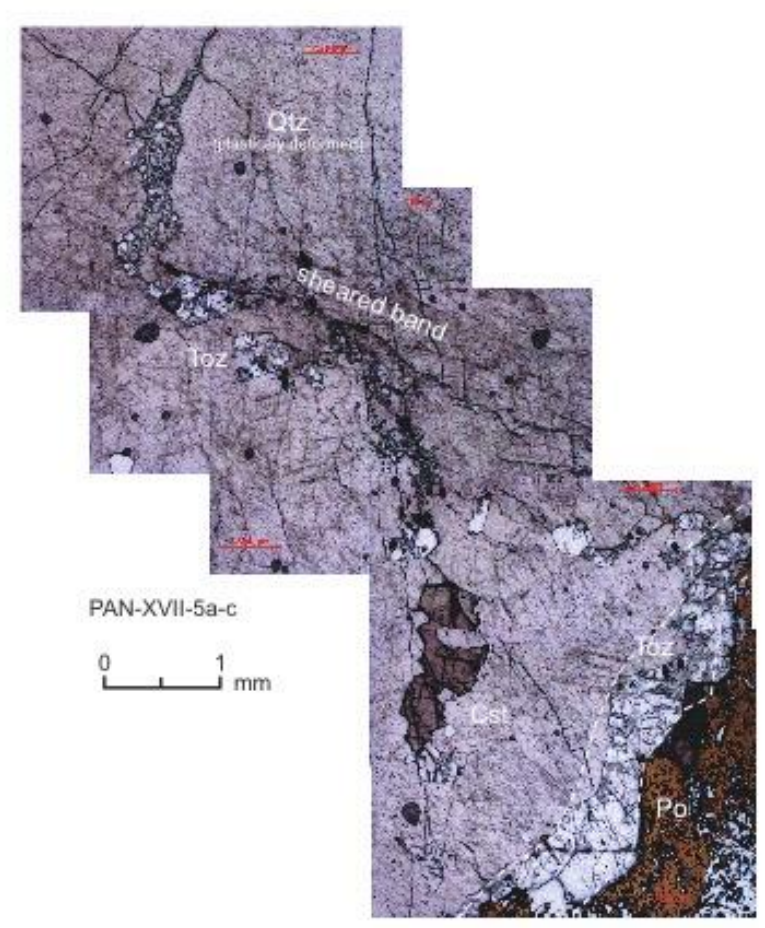

Figure 6

946 Fig. 6: Microphotograph of topaz along ductile micro-shear showing band the following 947 succession (transmitted light): Quartz I (Qtzl), association topaz (Toz) -cassiterite (Cst) as patches developed in Qtz I, topaz veinlet, and then final pyrrhotite (Po) infilling. 


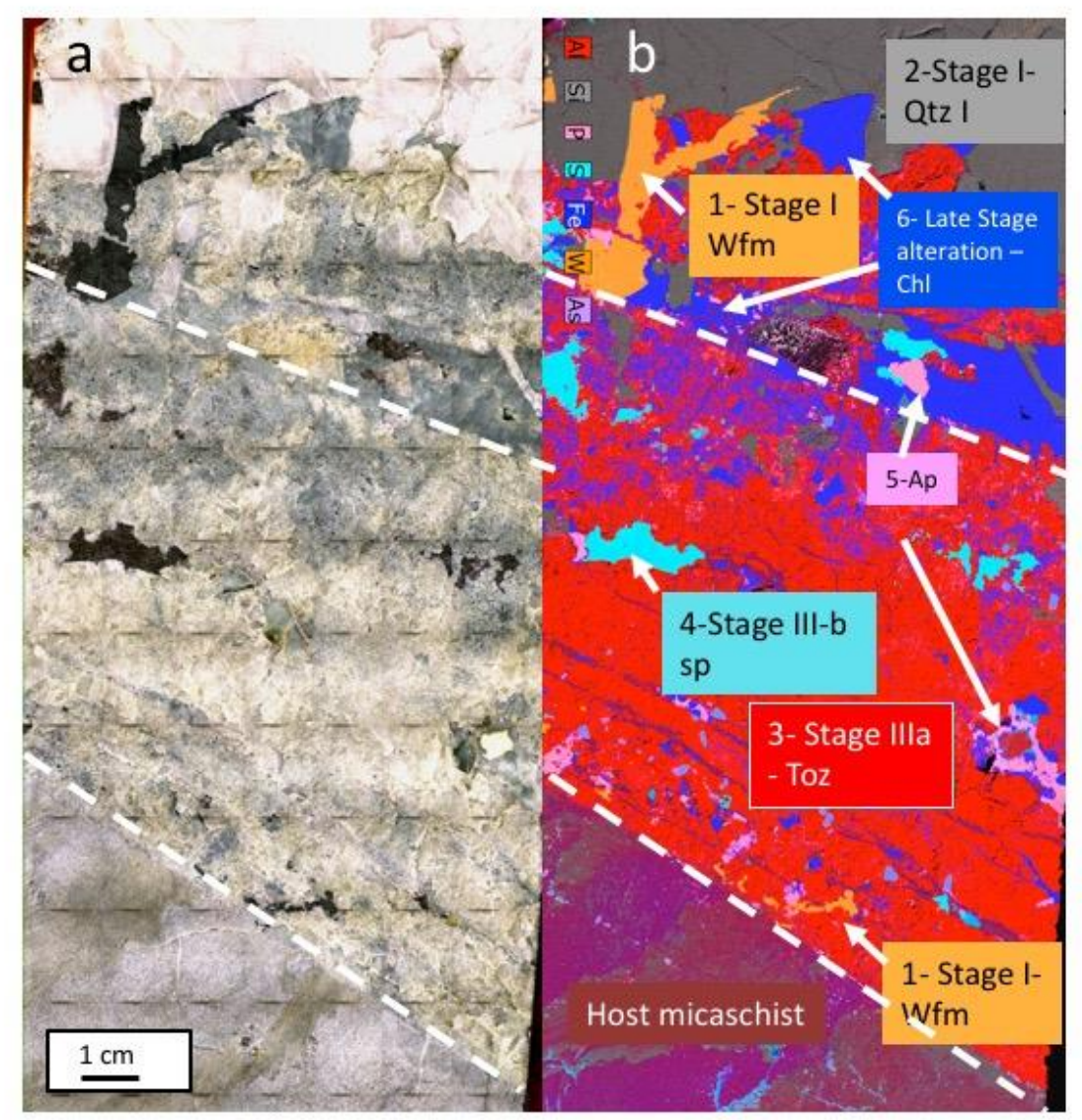

Figure 7

Fig. 7: Example of reopened quartz-wolframite vein boundary with the host micaschist followed by topaz infilling. a) photograph of the vein, b) micro-XRF element map (Al, Si, P, S, Fe, W, As) of the same sample and mineral distribution based on chemical element relative abundances: W (Wolframite: Wfm, W), Si (Quartz: Qtz, Si), Al (Topaz: Toz, Al), S (Sphalerite: Sph, Zn), P (Apatite: Ap, P), Fe (Chlorite: Chl, Fe-Si). Topaz is, in this sample, affected by later on alteration, in particular a replacement by Fe-chlorite. Wolframite is fragmented and embedded in topaz. 

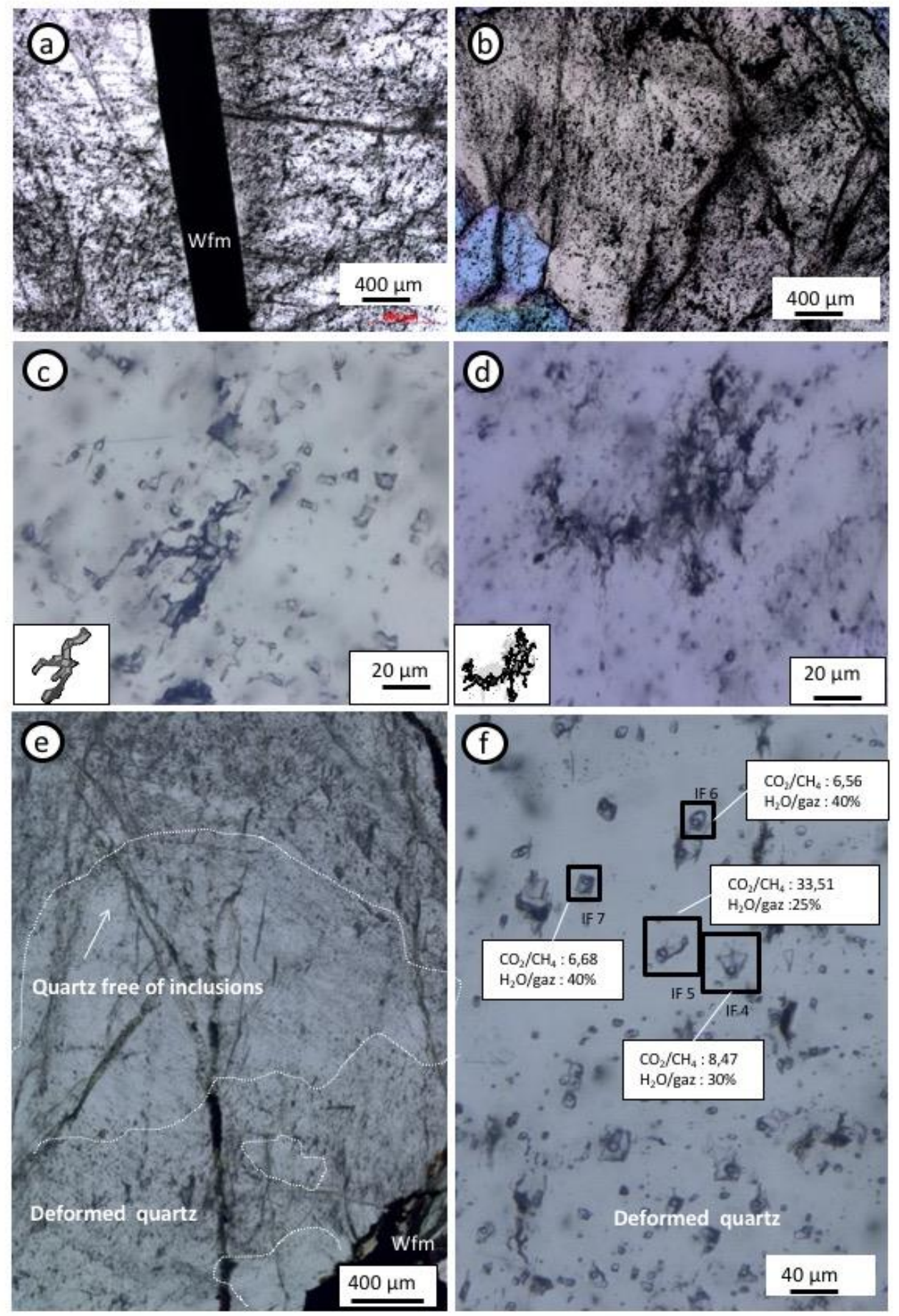

Figure 8

962 Fig. 8: Microphotographs of Stage I fluid inclusions in quartz QI (transmitted light). a) abundant decrepitated fluid inclusions close to wolframite in quartz Qtz I, b) deformed quartz Qtz I with clouds of decrepitated inclusions, c) and d) contorted fluid inclusions in quartz Qtz I, e) clear quartz domain within Qtz I identified by decrepitated inclusions, f) fluid inclusions with an indication of their $\mathrm{CO}_{2} / \mathrm{CH}_{4}$ ratios in the deformed Qtz I. 

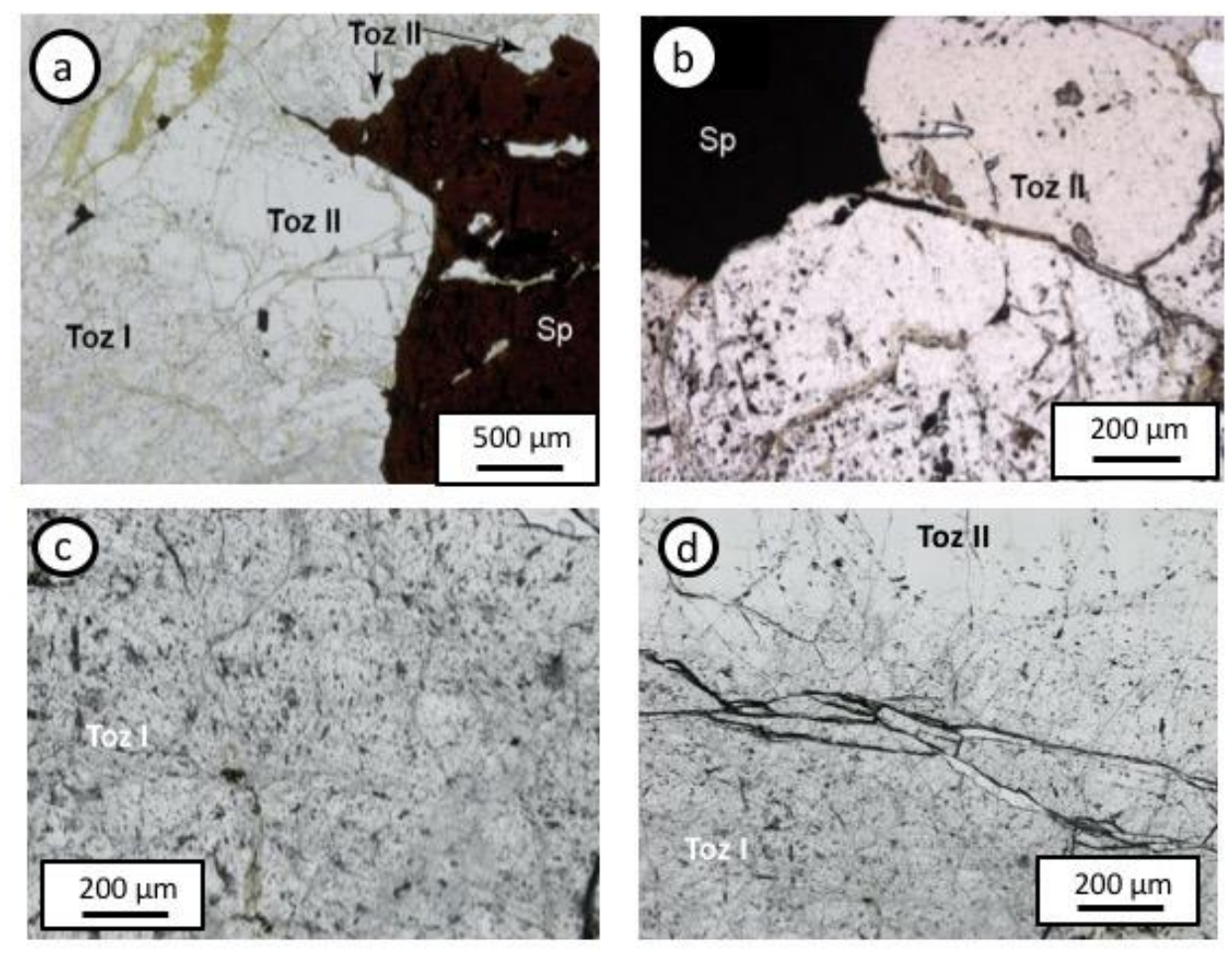

Fig. 9

Fig. 9: Microphotographs showing the fluid inclusion distribution in topaz: a) topaz overgrowth (Toz II) onto topaz I full of decrepitated inclusions (Toz I); b) clear Toz II in contact with sphalerite (Sp); c) detail of the decrepitated inclusions in Toz I, d) contact between Toz I and Toz II. 

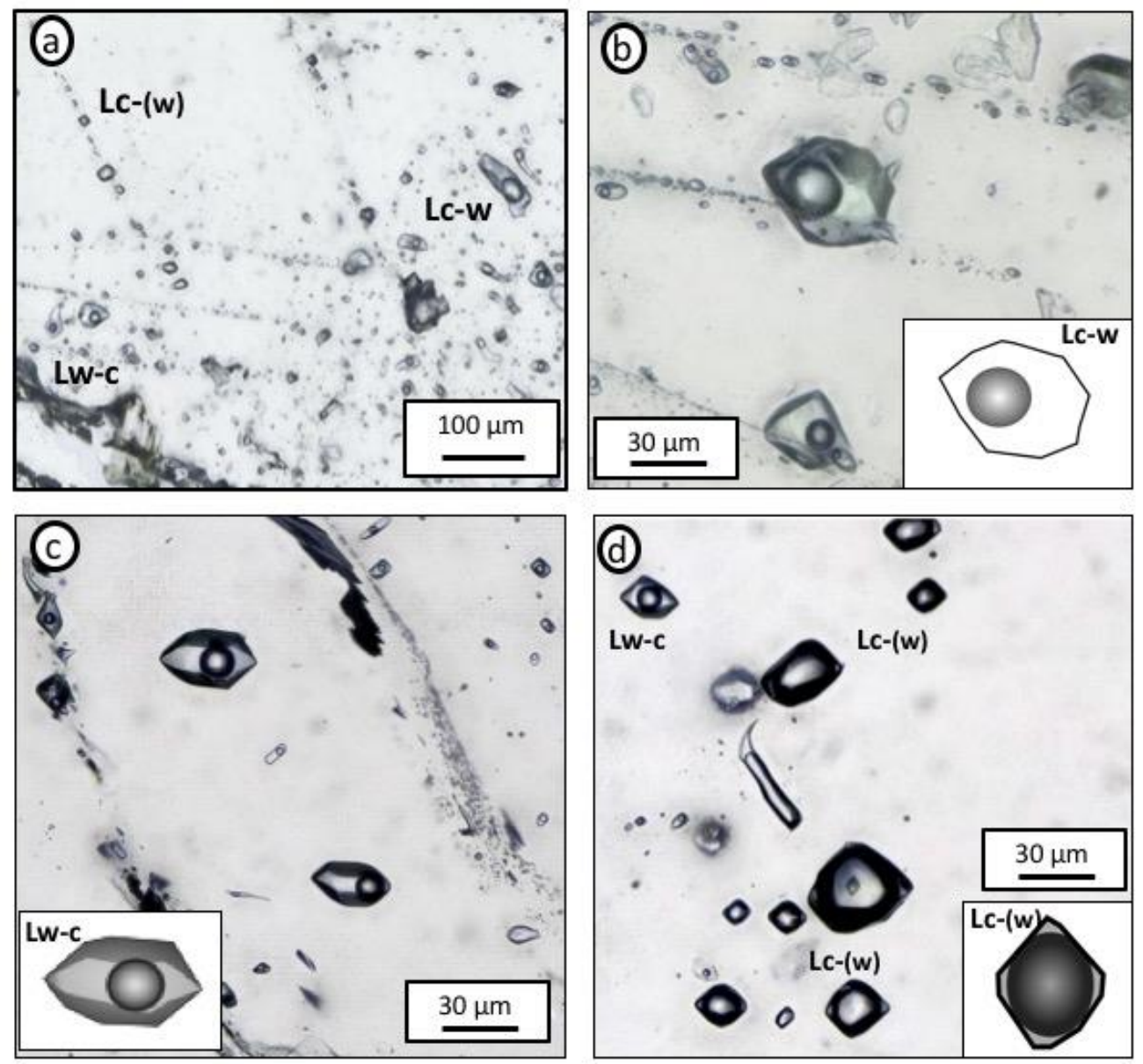

Figure 10

Fig. 10: Microphotographs of fluid inclusions types in topaz II: a) distribution of the three FI types, Lw-c, Lc-w, and Lc-(w) in Toz II. ), b) Lc-w inclusion; c) Lw-c inclusions, d) Lc-(w) inclusions in a pseudo-secondary plane. 


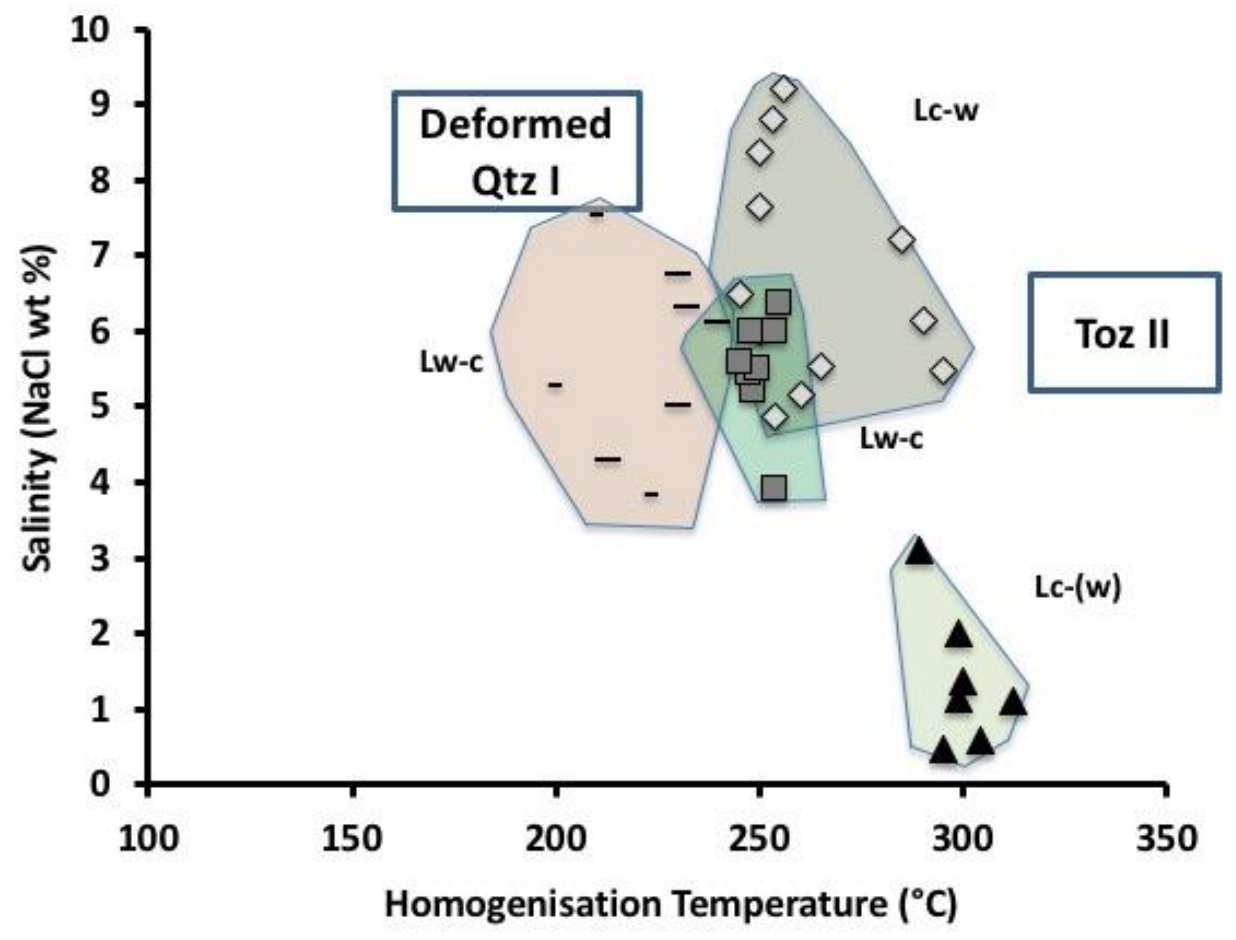

Fig. 11

Fig. 11: Th versus salinity plot for fluid inclusions types found in Topaz (Lw-C, LC-w, and LC982 (w)) and Quartz I. 


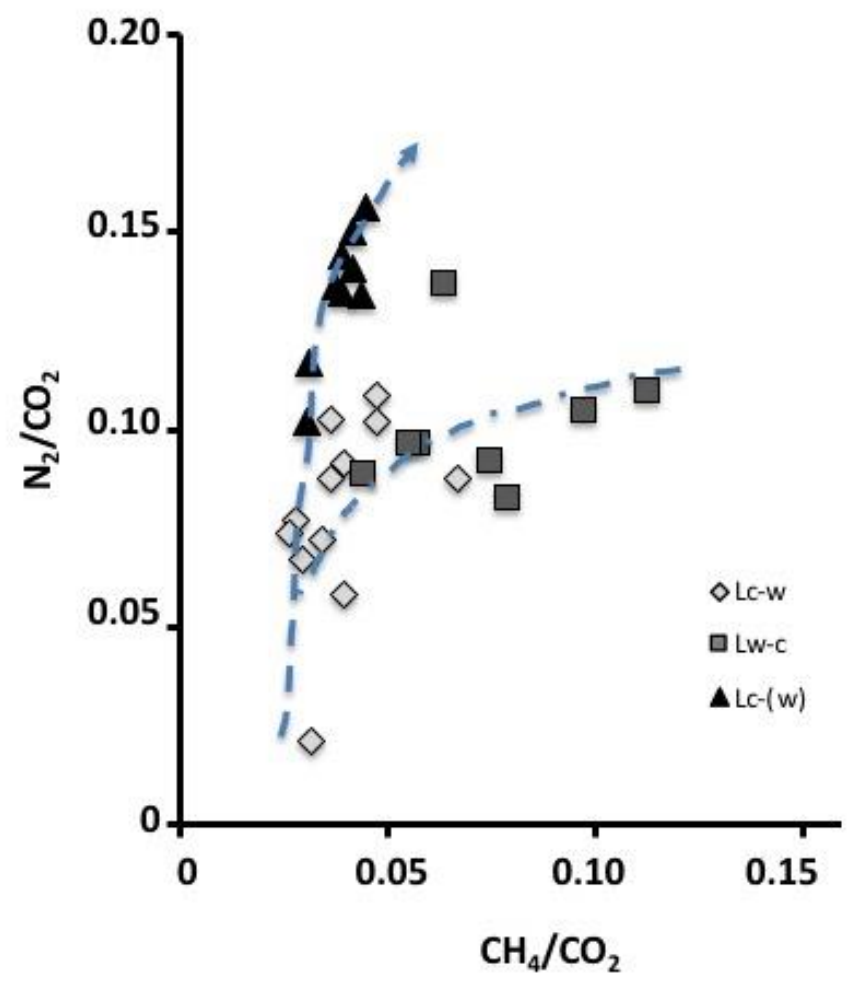

Fig. 12

987 Fig. 12: $\mathrm{N}_{2} / \mathrm{CO}_{2}$ versus $\mathrm{CH}_{4} / \mathrm{CO}_{2}$ plot for the volatile phase of the fluid inclusions types found 988 in topaz. 


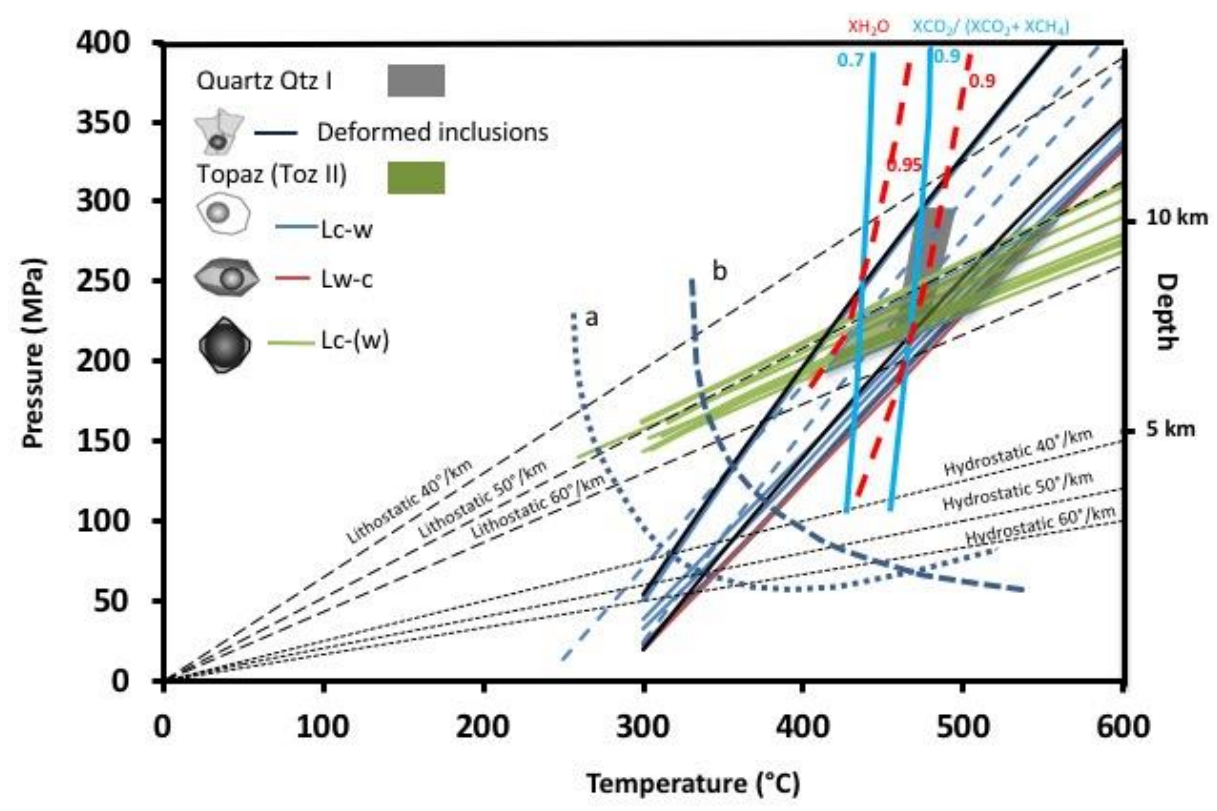

Fig. 13

Fig. 13: P-T diagram for stages I-II and III (Topaz II) at Panasqueira, with isochores of typical inclusions from each fluid inclusion type. Green box corresponds to the estimated pressure-temperature for the two stages. Isopleths for $\mathrm{XH}_{2} \mathrm{O}$ (thick red dashed lines) and $\mathrm{XCO}_{2} /\left(\mathrm{XCO}_{2}+\mathrm{XCH}_{4}\right)$ (thick blue lines) at $\mathrm{fO}_{2} \mathrm{QFM}$ (quartz-fayalite-magnetite) are from Huizenga (2001). Isopleths (dotted dark blue lines) in the system $\mathrm{H}_{2} \mathrm{O}-\mathrm{CO}_{2}-\mathrm{NaCl}$ are from Weisbrod (1984) for a salinity of 6 wt. \% $\mathrm{NaCl}$ equiv., and a $\mathrm{CO}_{2}$ content of 10 (a) and 20 (b) mole\%. 


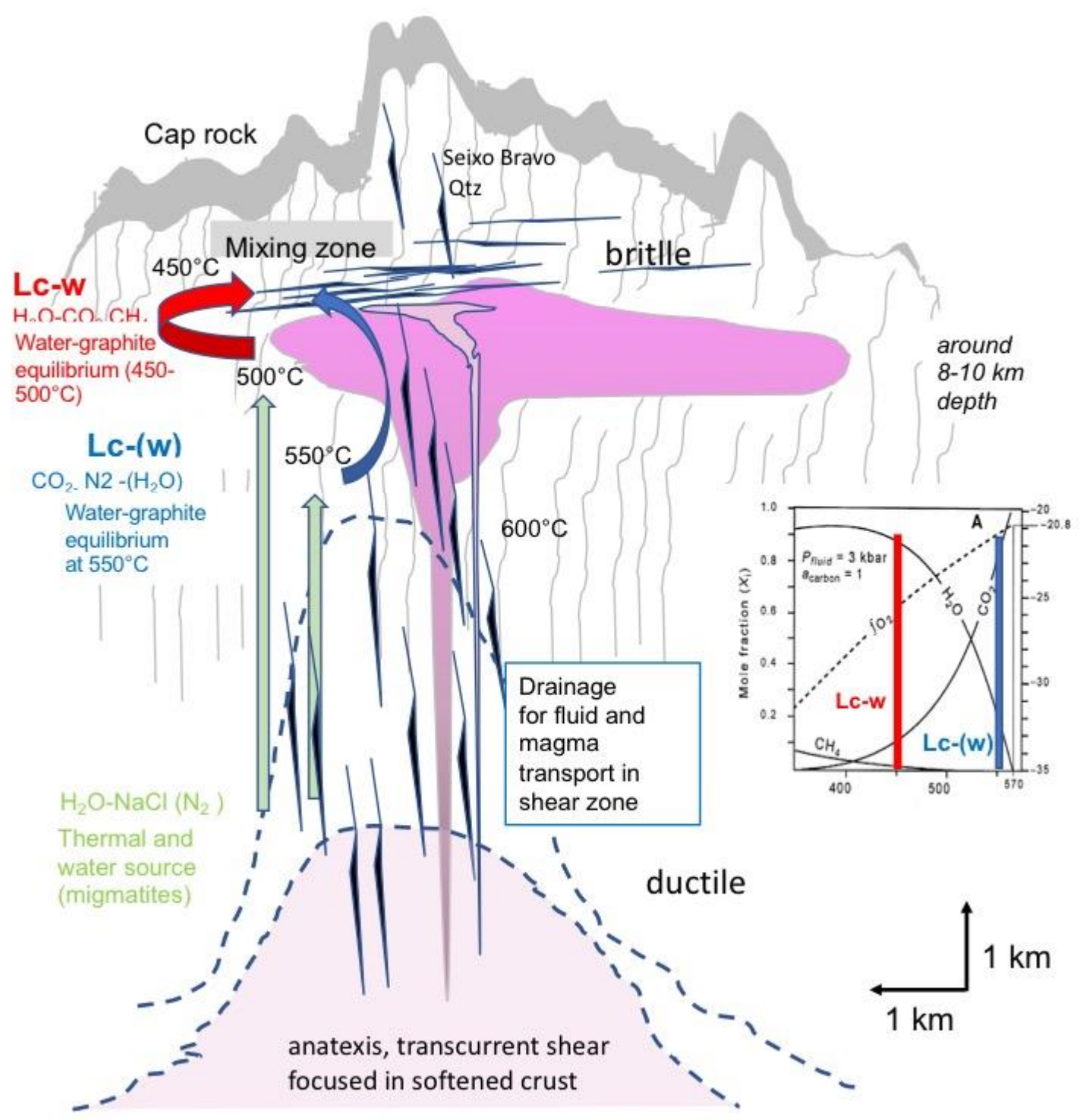

Fig. 14

Fig. 14: Sketch diagram of fluid circulation and mixing at Panasqueira with three postulated fluid sources: Deep-seated aqueous fluid source from likely anatectic domain, with medium salinity and significant $\mathrm{N}_{2}$ concentrations, fluids close to equilibrium with is inferred to occur in the sets of joints above the Panasqueira pluton. Late intrusions yielding to the formation of sills at the top of the Panasqueira granite are represented in pink. Inset showing $\mathrm{T}$-X diagram with $\mathrm{XH}_{2} \mathrm{O}, \mathrm{XCO}_{2}$, and $\mathrm{XCH}_{4}$ in equilibrium with graphite under QFM fO2 buffer as a function of temperature from Huizenga (2001): red line corresponds to the conditions of genesis of the Lc-w fluids and the blue line of the Lc-(w) fluids. 
1012

1013

1014

1015

\begin{tabular}{|c|c|c|c|c|c|c|c|c|}
\hline Mineral & FI type & $\mathrm{Tm} \mathrm{CO} 2$ & Th $\mathrm{CO}_{2}$ & mode & $\mathrm{Tm} \mathrm{Cl}$ & Tm ice & Th & mode \\
\hline Quartz I & Lw-C & $\begin{array}{c}-58.1 \text { to }-60.8 \\
4\end{array}$ & & & $\begin{array}{c}5.3 \text { to } 10.1 \\
14\end{array}$ & $\begin{array}{c}-4.6 \text { to }-7.8 \\
14\end{array}$ & $\begin{array}{c}198 \text { to } 232 \\
6\end{array}$ & $\mathrm{~L}$ \\
\hline Topaz & Lc-(w) & $\begin{array}{c}-58.7 \text { to }-60.0 \\
9\end{array}$ & $\begin{array}{c}10.3 \text { to } 12.5 \\
9\end{array}$ & $\mathrm{~L}$ & $\begin{array}{c}8.6 \text { to } 9.8 \\
9\end{array}$ & $\begin{array}{c}-4.9 \text { to }-7.1 \\
7\end{array}$ & $\begin{array}{c}289 \text { to } 312 \\
7\end{array}$ & $\mathrm{~V}$ \\
\hline & LC-W & $\begin{array}{c}-57.4 \text { to }-61.7 \\
16\end{array}$ & $\begin{array}{c}10.6 \text { to } 19.4 \\
9\end{array}$ & v & $\begin{array}{c}6.1 \text { to } 9.8 \\
16\end{array}$ & $\begin{array}{c}-4.4 \text { to }-6.9 \\
16\end{array}$ & $\begin{array}{c}250 \text { to } 295 \\
16\end{array}$ & L \\
\hline & Lw-c & $\begin{array}{c}-58.4 \text { to }-61.7 \\
3\end{array}$ & & & $\begin{array}{c}5.1 \text { to } 8.4 \\
8\end{array}$ & $\begin{array}{c}-4.3 \text { to }-6.9 \\
8\end{array}$ & $\begin{array}{c}245 \text { to } 255 \\
8\end{array}$ & L \\
\hline
\end{tabular}

1016

1017

1018

1019

1020

1021

1022

1023

Table captions

Table 1: Summary of the microthermometric data for Quartz I and Topaz II (first line: range, second line: number of measurements). L: homogenisation to the liquid phase, $\mathrm{V}$ : homogenisation to the vapour phase. See text for other abbreviations. All data are in ${ }^{\circ} \mathrm{C}$.

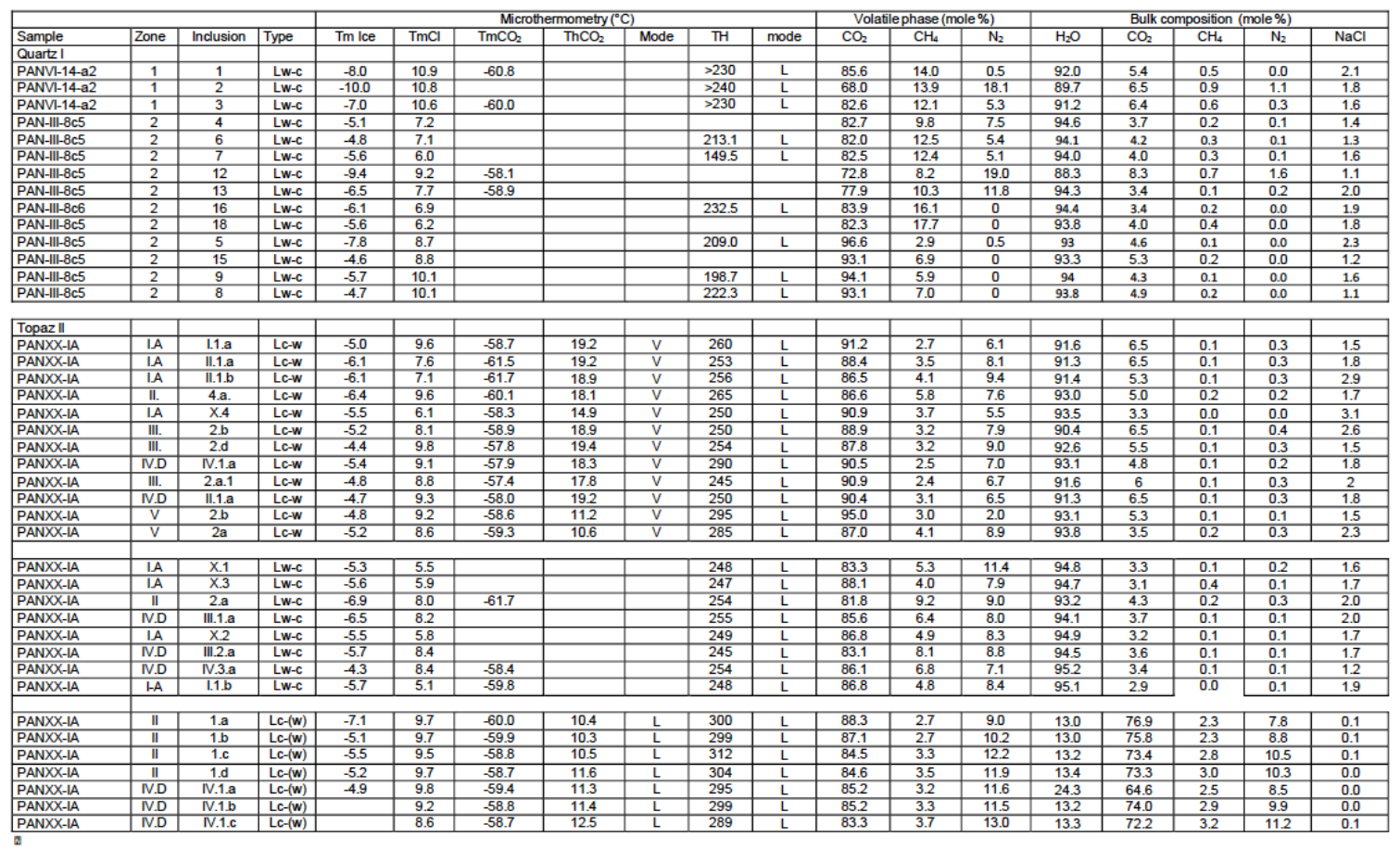

Table 2: Selected fluid inclusions with indications of microthermometric parameters, corresponding volatile phase composition from Raman spectroscopy, and calculated bulk compositions. L: homogenisation to the liquid phase, V: homogenisation to the vapour phase. See text for other abbreviations. 